\title{
Parasites, Bacteria, and Associated Pathological Changes in the Digestive System of Diurnal and Nocturnal Raptors in Central Italy
}

\author{
Giacomo Rossi $^{1}$ (D), Giuliana Terracciano ${ }^{2}$, Riccardo Gherardi ${ }^{3}$, Livio Galosi ${ }^{1}$ (D) and Stefania Perrucci ${ }^{3, *}$ \\ 1 School of Biosciences and Veterinary Medicine, University of Camerino, 62024 Matelica, Italy; \\ giacomo.rossi@unicam.it (G.R.); livio.galosi@unicam.it (L.G.) \\ 2 Istituto Zooprofilattico Sperimentale delle Regioni Lazio e Toscana, 56123 Pisa, Italy; \\ giuliana.terracciano@izslt.it \\ 3 Department of Veterinary Sciences, University of Pisa, 56124 Pisa, Italy; ric_gherardi@hotmail.com \\ * Correspondence: stefania.perrucci@unipi.it; Tel.: +39-050-2216949
}

Citation: Rossi, G.; Terracciano, G.; Gherardi, R.; Galosi, L.; Perrucci, S. Parasites, Bacteria, and Associated Pathological Changes in the Digestive System of Diurnal and Nocturnal Raptors in Central Italy. Pathogens 2021, 10, 1567. https://doi.org/ 10.3390 /pathogens10121567

Academic Editor: Geoff Hide

Received: 6 November 2021

Accepted: 26 November 2021

Published: 30 November 2021

Publisher's Note: MDPI stays neutral with regard to jurisdictional claims in published maps and institutional affiliations.

Copyright: (c) 2021 by the authors. Licensee MDPI, Basel, Switzerland. This article is an open access article distributed under the terms and conditions of the Creative Commons Attribution (CC BY) license (https:// creativecommons.org/licenses/by/ $4.0 /)$.

\begin{abstract}
The knowledge of raptor pathogens and associated lesions may be extremely important to enhancing raptor conservation efforts and reducing pathogen spillover to humans and domesticated animals and vice versa. Parasite infections of the digestive system and associated bacteria and pathological changes were evaluated in deceased diurnal and nocturnal raptors in central Italy. Overall, the prevalence of parasites (nematodes, cestodes, trematodes, acanthocephalans, and protozoa) identified in the examined birds was $72.41 \%$, and most of the positive raptors (71.42\%) showed multiple parasite infections. Among bacteria, Salmonella typhimurium, Salmonella enterica subspecies diarizonae, Escherichia coli, Clostridium perfringens, Yersinia enterocolitica, and Pasteurella multocida were identified. The results obtained showed that both parasites and bacteria may cause severe lesions in the digestive system of diurnal and nocturnal raptors; parasites and bacteria may concur in causing these lesions; most severe lesions are caused by the interaction of multiple pathogens, both parasites and bacteria; and the same pathogen taxa are frequently associated with the same pathological changes. This study is the first report of S. typhimurium and S. enterica subspecies diarizonae in Buteo buteo, while Andracantha mergi, Spirocerca spp., Sarcocystis dispersa, Sarcocystis columbae, and Eumonospora spp. were recorded for the first time in Italy.
\end{abstract}

Keywords: helminths; protozoa; bacteria; digestive system; pathological lesions; raptors; central Italy

\section{Introduction}

Raptors play a fundamental role in ecosystems as apex predators and scavengers and are considered biological indicators of environmental pollution. Therefore, studies on pathogens of raptors may provide useful data for ecosystem health monitoring, the evaluation of the health status of raptors populations, and the role these birds may play in spreading some important pathogens, such as drug-resistant bacteria and potentially zoonotic bacteria and parasites [1-4]. These animals are protected species in many countries, such as in Italy [5]. Nonetheless, worldwide, many raptor species are highly threatened [6]. In Italy, some diurnal and nocturnal raptors are currently included among endangered species, such as the marsh harrier (Circus aeruginosus), the Eleonora's falcon (Falco eleonorae), the Egyptian vulture (Neophron percnopterus), and the Eurasian pygmy owl (Glaucidium passerinum) [6].

Environmental deterioration and modifications due to human activities, in combination with other factors, such as direct persecution, are the main causes that are currently contributing to the decline of raptor populations [4,7-11]. The increase in urbanized areas and the conversion of natural environments to crop and livestock production with the destruction of wooded areas have greatly reduced habitats suitable for nesting, migratory stops, and hunting of raptors $[9,11]$. 
Furthermore, land reclamation interventions with the reduction in humid areas and the modernization of agricultural activities have caused the removal of hedges, trees, and old ruins that may play an important role in causing a decrease in the diversity of prey animals hunted by these birds and of refuge and rest places for both prey and predators $[9,11]$.

Pollution and pesticides and other drugs used in agricultural and zootechnical activities and ingestion of lead with the ingestion of shot prey may be responsible for acute or chronic poisoning of raptors, causing the death of these birds or negatively affecting their reproduction and ability to overcome diseases [12].

Moreover, many people and hunters still consider these birds as harmful to game animals, a disturbance for hunting from stationary stalking, or these birds are the subject of superstitions and popular beliefs, especially nocturnal raptors $[1,13,14]$. This is proved by the high number of shot and poisoned raptors recovered in wild animal centers during the hunting season each year [15].

Human activities may also contribute to the global dissemination of pathogens, thereby threatening wildlife [2,16]. Indeed, raptors are susceptible to several bacterial pathogens of humans and domestic animals [2] that are now considered contributing factors to the progressive decline of raptor populations $[17,18]$.

Although most parasitic infections appear to cause little or no distress to healthy individuals, parasites may be the cause of severe health issues when they occur in high numbers or when they are associated with other concurrent diseases or stressing factors $[19,20]$. Nevertheless, some protozoa and helminth species may affect raptor flying performance [21,22] and predatory effectiveness [23], as well as they may predispose raptors to secondary trauma [24]. Moreover, lesions caused by endoparasite species are often complicated by secondary bacterial infection [25]. However, some bacteria, such as Pasteurella multocida, Chlamydia, and Campylobacter species, are frequently reported as primary causes of infections and/or diseases in these birds [11,17,26-29].

Reports on the occurrence and pathological changes associated with parasites and bacteria in raptors are scarce [18,30-32]. Nevertheless, these data may be extremely useful to improve the knowledge on the impact these pathogens may have on raptor health and to evaluate whether their pathogenic role is linked to parasite infection intensity, to a specific parasite or bacterial species, and to the concurrence of parasites and bacteria $[20,25,30,31,33]$. Furthermore, wild birds may act as potential vectors or reservoirs of pathogens for domestic animals and are suspected sources for human bacterial infections $[2,17,27]$. Therefore, the knowledge of raptor pathogens may be extremely important to enhance bird conservation efforts and reduce pathogen spillover to other animals and humans [27].

In this study, protozoan and helminth infections of the digestive system and associated bacteria and pathological lesions were evaluated in deceased raptors in central Italy.

\section{Results and Discussion}

Most of the birds examined in this study were admitted to wildlife recovery centers and died from trauma, often caused by gunshot (Table 1). Nevertheless, catarrhal and/or hemorrhagic (gastro) enteritis and cachexia were frequently observed in raptors showing or not traumatic lesions (Table 1$)$.

Overall, the prevalence $(72.41 \%$ ) of parasites found in the digestive system of examined birds was high, as 21 out of 29 examined raptors scored positive for at least a parasite species. In most positive birds $(14 / 21,66.67 \%)$, the positivity for nematodes and protozoa was evidenced also at coprological analysis. Moreover, most of the positive raptors (15/21, $71.42 \%$ ) showed multiple parasite infections (Table 2), as frequently observed in previous European studies [24,30,33-38]. 
Table 1. Examined diurnal (12) and nocturnal (17) raptors deceased in wildlife rescue centers in Tuscany (central Italy) and the results of post-mortem gross examination.

\begin{tabular}{|c|c|c|c|c|c|}
\hline & $\begin{array}{l}\text { Common Name } \\
\text { and Identification } \\
\text { Number }\end{array}$ & Species & Sex & $\begin{array}{c}\text { Age } \\
\text { (Young/Adult) }\end{array}$ & Necropsy (post-mortem Gross Examination) \\
\hline \multicolumn{6}{|c|}{ Diurnal Raptors } \\
\hline 1 & Osprey 1 & Pandion haliaetus & Male & Young & Reduced muscle mass and enteritis \\
\hline 2 & Common buzzard 1 & Buteo buteo & Female & Adult & $\begin{array}{c}\text { Left ulna fracture due to a gunshot and cranial } \\
\text { hematoma }\end{array}$ \\
\hline 3 & Common buzzard 2 & B. buteo & Female & Adult & $\begin{array}{l}\text { Dehydration and reduced muscle mass; cloaca, left } \\
\text { oviduct, and right ventricle enlarged; congestion } \\
\text { of the gastric and small intestine mucosa }\end{array}$ \\
\hline 4 & Common buzzard 3 & B. buteo & Male & Young & $\begin{array}{l}\text { Severe anemia; reduced and pale muscle masses; } \\
\text { head trauma; hypertrophic heart; the presence of } \\
\text { mucus in the esophagus }\end{array}$ \\
\hline 5 & Common buzzard 4 & B. buteo & Male & Young & $\begin{array}{l}\text { Gunshot wound with an open fracture of the right } \\
\text { humerus; reduced muscle mass; necrotic } \\
\text { esophageal fistulous lesions; thickened thoracic air } \\
\text { sacs and pneumonia }\end{array}$ \\
\hline 6 & Honey buzzard 1 & Pernis apivorus & Male & Young & Reduced muscle mass; necrotic esophageal lesions \\
\hline 7 & Honey buzzard 2 & P. apivorus & Male & Young & $\begin{array}{l}\text { Severe weight loss and dehydration; mild catarrhal } \\
\text { enteritis; hepatomegaly and nephromegaly }\end{array}$ \\
\hline 8 & Sparrowhawk 1 & Accipiter nisus & Male & Young & Severe cachexia and catarrhal enteritis \\
\hline 9 & Sparrowhawk 2 & A. nisus & Female & Adult & $\begin{array}{l}\text { Fracture of the left humerus for a gunshot; necrotic } \\
\text { enteritis; and the presence of digested blood in the } \\
\text { stomach and in the intestine }\end{array}$ \\
\hline 10 & Sparrowhawk 3 & A. nisus & Female & Adult & $\begin{array}{l}\text { Right paw dermatitis; old fracture of the humerus; } \\
\text { hemorrhagic gastroenteritis and fibrin deposits in } \\
\text { the air sacs; liver dark red in color }\end{array}$ \\
\hline 11 & Common kestrel 1 & Falco tinnunculus & Female & Adult & $\begin{array}{l}\text { Fracture of the right tarsometatarsal joint; serous } \\
\text { collection in the thoracoabdominal cavity and } \\
\text { catarrhal-hemorrhagic enteritis }\end{array}$ \\
\hline 12 & Common kestrel 2 & F. tinnunculus & Female & Adult & Reduced muscle mass \\
\hline \multicolumn{6}{|c|}{ Nocturnal Raptors } \\
\hline 13 & Barn owl 1 & Tyto alba & - & Adult & Enteritis \\
\hline 14 & Barn owl 2 & T. alba & Male & Adult & Cachexia and hemorrhagic and catarrhal enteritis \\
\hline 15 & Little owl 1 & Athene noctua & Female & Adult & Congested kidneys \\
\hline 16 & Little owl 2 & A. noctua & Female & Young & Reduced muscle mass \\
\hline 17 & Little owl 3 & A. noctua & Male & Young & Very young subject, still not fully able to fly \\
\hline 18 & Little owl 4 & A. noctua & Male & Young & Very young subject, still not fully able to fly \\
\hline 19 & Little owl 5 & A. noctua & Male & Young & $\begin{array}{l}\text { Very young subject, still not fully able to fly; } \\
\text { reduced muscle mass }\end{array}$ \\
\hline 20 & Little owl 6 & A. noctua & Male & Young & $\begin{array}{l}\text { Mild congestion of the mucous membrane of the } \\
\text { first intestinal tract, cloacal obstruction }\end{array}$ \\
\hline 21 & Little owl 7 & A. noctua & Female & Young & Very young subject, still not fully able to fly \\
\hline 22 & Little owl 8 & A. noctua & Male & Young & Very young subject, still not fully able to fly \\
\hline 23 & Little owl 9 & A. noctua & Male & Young & Cachexia. \\
\hline 24 & Little owl 10 & A. noctua & Male & Young & Very young subject, still not fully able to fly \\
\hline
\end{tabular}


Table 1. Cont.

\begin{tabular}{|c|c|c|c|c|c|}
\hline & $\begin{array}{l}\text { Common Name } \\
\text { and Identification } \\
\text { Number }\end{array}$ & Species & Sex & $\begin{array}{c}\text { Age } \\
\text { (Young/Adult) }\end{array}$ & Necropsy (post-mortem Gross Examination) \\
\hline 25 & Little owl 11 & A. noctua & Female & Adult & Spinal cord hematoma \\
\hline 26 & Little owl 12 & A. noctua & Female & Adult & $\begin{array}{l}\text { Gunshot wound in the pectoral muscles and on } \\
\text { the right side of the neck; enteritis, lungs } \\
\text { congested and hemorrhagic }\end{array}$ \\
\hline 27 & Little owl 13 & A. noctua & Female & Adult & Cachexia, nephritis, and pulmonary congestion \\
\hline 28 & Scops owl 1 & Otus scops & Male & Adult & $\begin{array}{c}\text { Gunshot wound to the right wing; reduced muscle } \\
\text { mass and pyoderma in the sternal region }\end{array}$ \\
\hline 29 & Scops owl 2 & O. scops & Male & Young & $\begin{array}{l}\text { Enlarged stomach with catarrhal-hemorrhagic } \\
\text { gastroenteritis and necrotic areas in the liver }\end{array}$ \\
\hline
\end{tabular}

Among identified parasites, helminths and especially nematodes (20/21, 95.23\%) were more frequently recorded, as all positive raptors scored positive for these parasites, except for a barn owl found infected only by protozoa (Table 2). Capillariid nematodes were found in almost all the raptor species here examined and in most of the positive birds $(15 / 21$, $71.42 \%)$, followed by Procyrnea spp. (10/21, $47.61 \%)$, even if these latter nematodes were more frequently found among diurnal raptors (Table 2). Trematodes and, mainly, cestodes were more rarely found (Table 2).

Acanthocephalans were also frequently identified, especially in diurnal raptors (Table 2), while Sarcocystis spp. and Eumonospora spp. protozoa were identified in a few birds (Table 2).

Most of the pathogens identified in this study are commonly found in European diurnal and nocturnal raptors $[8,23,24,30,35,37-46]$.

Lesions of different typologies and levels of severity were evidenced at histopathological analysis in the different digestive tracts of the examined raptors (Table 3).

Moreover, among selected bacteria, secondary bacterial infection and bacteria considered primary causes of infections and/or diseases in these birds were identified at bacteriological analysis (Table 4) [11,17,26-29]. 
Table 2. Endoparasite species (Phylum: Family) identified in the digestive system of examined raptors.

\begin{tabular}{|c|c|c|c|c|c|c|}
\hline Animal & Infected Organs & Nematodes & Cestodes & Trematodes & Acanthocephala & Protozoa \\
\hline Osprey 1 & $\begin{array}{l}\text { Gizzard, Proventriculus, } \\
\text { Intestine }\end{array}$ & $\begin{array}{c}\text { Procyrnea leptoptera } \\
\text { (Nematoda: Habronematidae) } 3 \text { * }\end{array}$ & - & - & $\begin{array}{l}\text { Andracantha mergi } \\
\text { (Acanthocephala: } \\
\text { Polymorphidae) } 2 \text { * }\end{array}$ & - \\
\hline Common buzzard 1 & $\begin{array}{l}\text { Gizzard, Proventriculus, } \\
\text { Intestine }\end{array}$ & $\begin{array}{c}\text { Physaloptera alata } 1 \text { * (Nematoda: } \\
\text { Physalopteridae) } \\
\text { Porrocaecum angusticolle } \\
\text { (Nematoda: Ascarididae) } 1 \text { * } \\
\text { Baruscacapillaria falconis } \\
\text { (Nematoda: Capillariidae) } 3 * \\
\text { Procyrnea mansioni (Nematoda: } \\
\text { Habronematidae) } 7 \text { * }\end{array}$ & - & - & $\begin{array}{c}\text { Centrorhynchus } \\
\text { globocaudatus } \\
\text { (Acanthocephala: } \\
\text { Centrorhynchidae) } 80 *\end{array}$ & - \\
\hline Common buzzard 2 & $\begin{array}{l}\text { Gizzard, Proventriculus, } \\
\text { Intestine }\end{array}$ & $\begin{array}{l}\text { Procyrnea mansioni (Nematoda: } \\
\text { Habronematidae) } 1 * \\
\text { Porrocaecum angusticolle } \\
\text { (Nematoda: Ascarididae) } 1 * \\
\text { Baruscacapillaria falconis } \\
\text { (Nematoda: Capillariidae) } 2 * \\
\text { Spirocerca spp. encysted larvae } \\
\text { (Nematoda: Thelaziidae) } 4 *\end{array}$ & - & $\begin{array}{c}\text { Neodiplostomum } \\
\text { attenuatum } \\
\text { (Platyhel-minthes: } \\
\text { Diplostomatidae) 2* }\end{array}$ & $\begin{array}{c}\text { Centrorhynchus } \\
\text { globocaudatus } \\
\text { (Acanthocephala: } \\
\text { Centrorhynchidae) } 2 *\end{array}$ & - \\
\hline Common buzzard 3 & $\begin{array}{l}\text { Esophagous, Gizzard, } \\
\text { Proventriculus, Intestine }\end{array}$ & $\begin{array}{c}\text { Eucoleus dispar (Nematoda: } \\
\text { Capillariidae) } 4 * \\
\text { Porrocaecum angusticolle } \\
\text { (Nematoda: Ascarididae) } 6 * \\
\text { Baruscacapillaria falconis } \\
\text { (Nematoda: Capillariidae) } 13 * \\
\text { Procyrnea mansioni (Nematoda: } \\
\text { Habronematidae) } 50 *\end{array}$ & - & $\begin{array}{c}\text { Neodiplostomum } \\
\text { attenuatum } \\
\text { (Platyhel-minthes: } \\
\text { Diplostomatidae) } 50 \text { * }\end{array}$ & $\begin{array}{l}\text { Centrorhynchus aluconis } \\
\text { (Acanthocephala: } \\
\text { Centrorhynchidae) 9* }\end{array}$ & - \\
\hline Common buzzard 4 & $\begin{array}{l}\text { Esophagous, Gizzard, } \\
\text { Proventriculus, Intestine }\end{array}$ & $\begin{array}{c}\text { Eucoleus dispar (Nematoda: } \\
\text { Capillariidae) } 5 * \\
\text { Porrocaecum angusticolle } \\
\text { (Nematoda: Ascarididae) } 1 \text { * } \\
\text { Baruscacapillaria falconis } \\
\text { (Nematoda: Capillariidae) } 3 \text { * } \\
\text { Procyrnea mansioni (Nematoda: } \\
\text { Habronematidae) } 2 *\end{array}$ & $\begin{array}{l}\text { Cladotaenia globifera } \\
\text { (Platyhelminthes: } \\
\text { Paruterinidae) } 9 *\end{array}$ & - & $\begin{array}{l}\text { Centrorhynchus aluconis } \\
\text { (Acanthocephala: } \\
\text { Centrorhynchidae) } 20 \text { * }\end{array}$ & - \\
\hline
\end{tabular}


Table 2. Cont.

\begin{tabular}{|c|c|c|c|c|c|c|}
\hline Animal & Infected Organs & Nematodes & Cestodes & Trematodes & Acanthocephala & Protozoa \\
\hline Honey buzzard 1 & $\begin{array}{l}\text { Esophagous, Gizzard, } \\
\text { Intestine }\end{array}$ & $\begin{array}{c}\text { Eucoleus dispar (Nematoda: } \\
\text { Capillariidae) } 1 \text { * } \\
\text { Physaloptera apivori (Nematoda: } \\
\text { Physalopteridae) } 4^{*}\end{array}$ & $\begin{array}{l}\text { Raillietina apivori } \\
\text { (Platyhelminthes: } \\
\text { Davaineidae) } 1^{*}\end{array}$ & - & - & - \\
\hline Honey buzzard 2 & $\begin{array}{c}\text { Esophagous, Gizzard, } \\
\text { Proventriculus, Intestine }\end{array}$ & $\begin{array}{c}\text { Eucoleus dispar (Nematoda: } \\
\text { Capillariidae) } 4 \text { * } \\
\text { Procyrnea leptoptera (Nematoda: } \\
\text { Habronematidae) } 7^{*} \\
\text { Baruscacapillaria falconis } \\
\text { (Nematoda: Capillariidae) } 2 \text { * }\end{array}$ & - & - & - & - \\
\hline Sparrowhawk 1 & $\begin{array}{c}\text { Gizzard, Proventriculus, } \\
\text { Intestine }\end{array}$ & $\begin{array}{c}\text { Procyrnea leptoptera (Nematoda: } \\
\text { Habronematidae) } 7 * \\
\text { Physaloptera alata } \\
\text { (Nematoda: Physalopteridae) } 1 \text { * } \\
\text { Synhimantus laticeps (Nematoda: } \\
\text { Acuariidae) } 2 \text { * } \\
\text { Baruscacapillaria falconis } \\
\text { (Nematoda: Capillariidae) } 7 \text { * }\end{array}$ & - & - & - & - \\
\hline Sparrowhawk 2 & $\begin{array}{c}\text { Gizzard, Proventriculus, } \\
\text { Intestine }\end{array}$ & $\begin{array}{c}\text { Baruscacapillaria falconis } \\
\text { (Nematoda: Capillariidae) } 3 * \\
\text { Procyrnea leptoptera (Nematoda: } \\
\text { Habronematidae) } 2^{*} \\
\text { Spirocerca spp. encysted larvae } \\
\text { (Nematoda: Thelaziidae) } 3 *\end{array}$ & - & - & - & $\begin{array}{l}\text { Sarcocystis columbae } \\
\text { (Apicomplexa: } \\
\text { Sarcocystidae) heavy } \\
\text { infections }\end{array}$ \\
\hline Sparrowhawk 3 & Intestine & $\begin{array}{c}\text { Baruscacapillaria falconis } \\
\text { (Nematoda: Capillariidae) } 9 * \\
\text { Porrocaecum angusticolle } \\
\text { (Nematoda: Ascarididae) } 3 *\end{array}$ & - & - & - & - \\
\hline Common kestrel 1 & Intestine & $\begin{array}{c}\text { Spirocerca spp. (Nematoda: } \\
\text { Thelaziidae) } 2^{*} \\
\text { Diplotriaena falconis (Nematoda, } \\
\text { Diplotriaenidae) } 6^{*}\end{array}$ & - & $\begin{array}{c}\text { Neodiplostomum } \\
\text { spathoides } \\
\text { (Platyhel-minthes: } \\
\text { Diplostomatidae) } 1 *\end{array}$ & - & - \\
\hline
\end{tabular}


Table 2. Endoparasite species (Phylum: Family) identified in the digestive system of examined raptors.

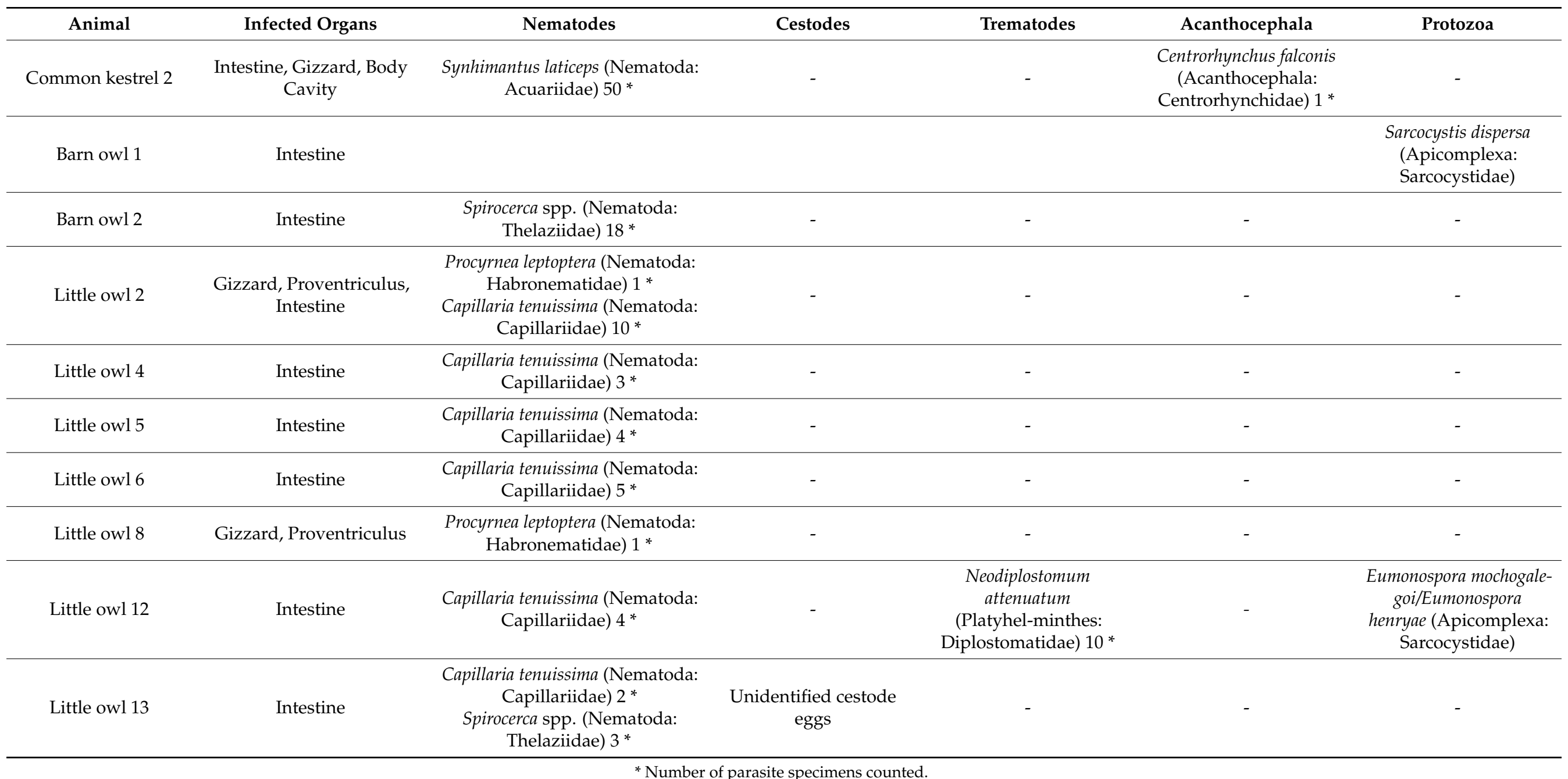




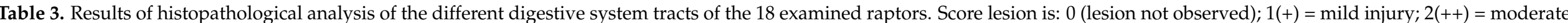
injury; $3(+++)=$ severe injury. NS = organ not sampled.

\begin{tabular}{|c|c|c|c|c|c|c|}
\hline Raptor Species & Esophagus & Proventriculus & Gizzard & Duodenum & Jejunum/Ileum & Colon \\
\hline Common buzzard (B. buteo) 1 & ns & 0 & $\mathrm{D} 2+++$ & 0 & 0 & $\mathrm{D}+++$ \\
\hline Common buzzard (B. buteo) 2 & ns & D1 +++ & $\mathrm{G}+$ & 0 & $\mathrm{E}++$ & $\mathrm{D}++; \mathrm{F}+$ \\
\hline Common buzzard (B. buteo) 4 & $\mathrm{C}++$ & $\mathrm{A}+++, \mathrm{D} 1+$ & $\mathrm{B}+, \mathrm{D}++$ & $\mathrm{A}+++$ & $\mathrm{A}+, \mathrm{F}+, \mathrm{G}++$ & 0 \\
\hline European honey buzzard (P. apivorus) 1 & $\mathrm{~F}+$ & $\mathrm{G}+$ & 0 & 0 & $\mathrm{~F}+$ & $\mathrm{E}++; \mathrm{F}+++$ \\
\hline European honey buzzard (P. apivorus) 2 & $\mathrm{D}+$ & $\mathrm{D} 1++$ & $\mathrm{D} 2++$ & $\mathrm{C}+++$ & $\mathrm{B} ; \mathrm{C}+$ & $\mathrm{C}++$ \\
\hline Eurasian sparrowhawk (A. nisus) 1 & ns & ns & ns & $\mathrm{B}++$ & $A+$ & 0 \\
\hline Eurasian sparrowhawk (A. nisus) 2 & ns & $\mathrm{D} 1++$ & $\mathrm{D}+$ & $\mathrm{C} 3+++; \mathrm{F}+$ & $\mathrm{C} 2++; \mathrm{C} 3+$ & $\mathrm{C} 2+++; \mathrm{C} 4++$ \\
\hline Eurasian sparrowhawk (A. nisus) 3 & ns & 0 & 0 & $\mathrm{C} 3++; \mathrm{F}+$ & $\mathrm{F}+$ & 0 \\
\hline Common kestrel (F. tinnunculus) 1 & 0 & $\mathrm{G}+$ & 0 & 0 & $\mathrm{D}++; \mathrm{F}+$ & $\mathrm{C} 2+++; \mathrm{C} 4++$ \\
\hline Common kestrel (F. tinnunculus) 2 & ns & 0 & 0 & 0 & 0 & 0 \\
\hline Barn owl (T. alba) 2 & ns & 0 & $\mathrm{D}+++$ & 0 & $\mathrm{D}+$ & 0 \\
\hline Little owl (A. noctua) 2 & $\mathrm{~ns}$ & 0 & 0 & 0 & $\mathrm{~A}+$ & 0 \\
\hline Little owl (A. noctua) 5 & ns & 0 & 0 & $\mathrm{C}+$ & $\mathrm{C}+$ & 0 \\
\hline Little owl $($ A. noctua $) 6$ & ns & $\mathrm{D}+$ & 0 & 0 & $\mathrm{E}+$ & 0 \\
\hline Little owl (A. noctua) 12 & $\mathrm{~ns}$ & $\mathrm{D}+$ & 0 & 0 & $\mathrm{C}++; \mathrm{C} 3+++$ & $\mathrm{A}+++$ \\
\hline Little owl (A. noctua) 13 & ns & $\mathrm{C}+++$ & $C+$ & $\mathrm{C} 1+++$ & $\mathrm{C} 1++$ & $\mathrm{C}++$ \\
\hline
\end{tabular}

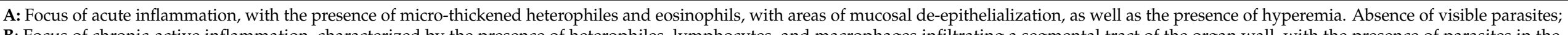

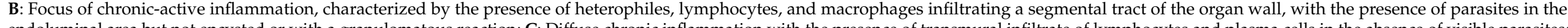

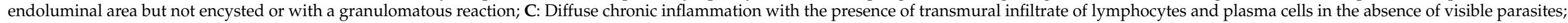

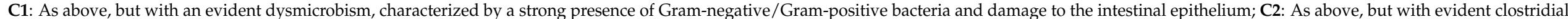

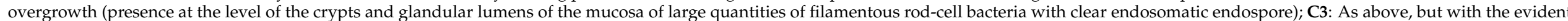

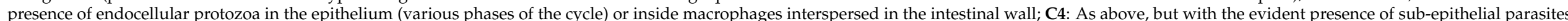

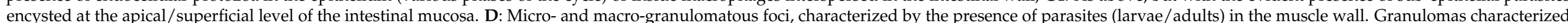

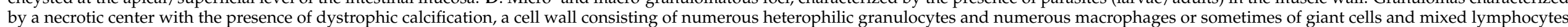

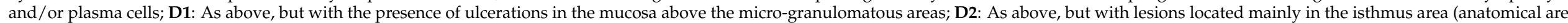

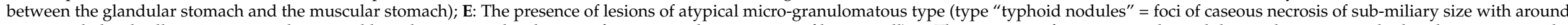

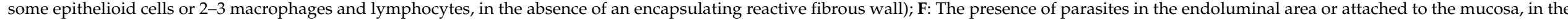
absence of specific lesions; G: The presence of parasites inside the muscle fibers of the wall, in the absence of pericystic reaction (with few calcified cysts). 
Table 4. Selected bird bacteria identified in examined raptors.

\begin{tabular}{ccc}
\hline Animal & Organ & Bacteria \\
\hline Common buzzard 2 & $\begin{array}{c}\text { Liver and intestine (and } \\
\text { lungs) }\end{array}$ & $\begin{array}{c}\text { Salmonella typhimurium } \\
(4,5,12: \text { i: } 1,2) \text { Gr O: } 4 \text { (B) }\end{array}$ \\
\hline Common buzzard 3 & Liver and intestine & $\begin{array}{c}\text { Salmonella enterica subspecies } \\
\text { diarizonae IIIb } \\
(50: \text { r: } 1,5.7) \text { Gr O: } 50 \text { (Z) }\end{array}$ \\
\hline Honey buzzard 1 & Intestine & $\begin{array}{c}\text { Salmonella typhimurium } \\
(4,5,12: \text { i: 1,2) Gr O: 4 (B) }\end{array}$ \\
\hline Honey buzzard 2 & Liver (and brain) & Escherichia coli \\
\hline Sparrowhawk 2 & Intestine & Clostridium perfringens \\
\hline Common kestrel 1 & Intestine (and brain) & $\begin{array}{c}\text { Yersinia enterocolitica } \\
\text { Pasteurella multocida }\end{array}$ \\
\hline Little owl 6 & Liver & Escherichia coli \\
\hline Little owl 13 & Liver (and brain) & Pasteurella multocida \\
\hline
\end{tabular}

Among examined diurnal raptor species, all buzzards were found infected by Procyrnea mansioni in the gizzard and proventriculus, Porrocoecum angusticolle and Baruscapillaria falconis in the small intestine and Centrorhynchus spp. in the large intestine, although in some cases, the infection intensity was very different among the examined buzzards (Table 2, Figures 1 and 2). Moreover, Eucoleus dispar in the esophagus of the common buzzards 3 and 4, Physaloptera alata in the gizzard of the common buzzard 1, Neodiplostomum attenuatum and Spirocerca spp. in the intestine of the common buzzard 2, and Cladotaenia globifera cestodes in the intestine of the common buzzard 4, were also identified (Table 2, Figures 1 and 2).

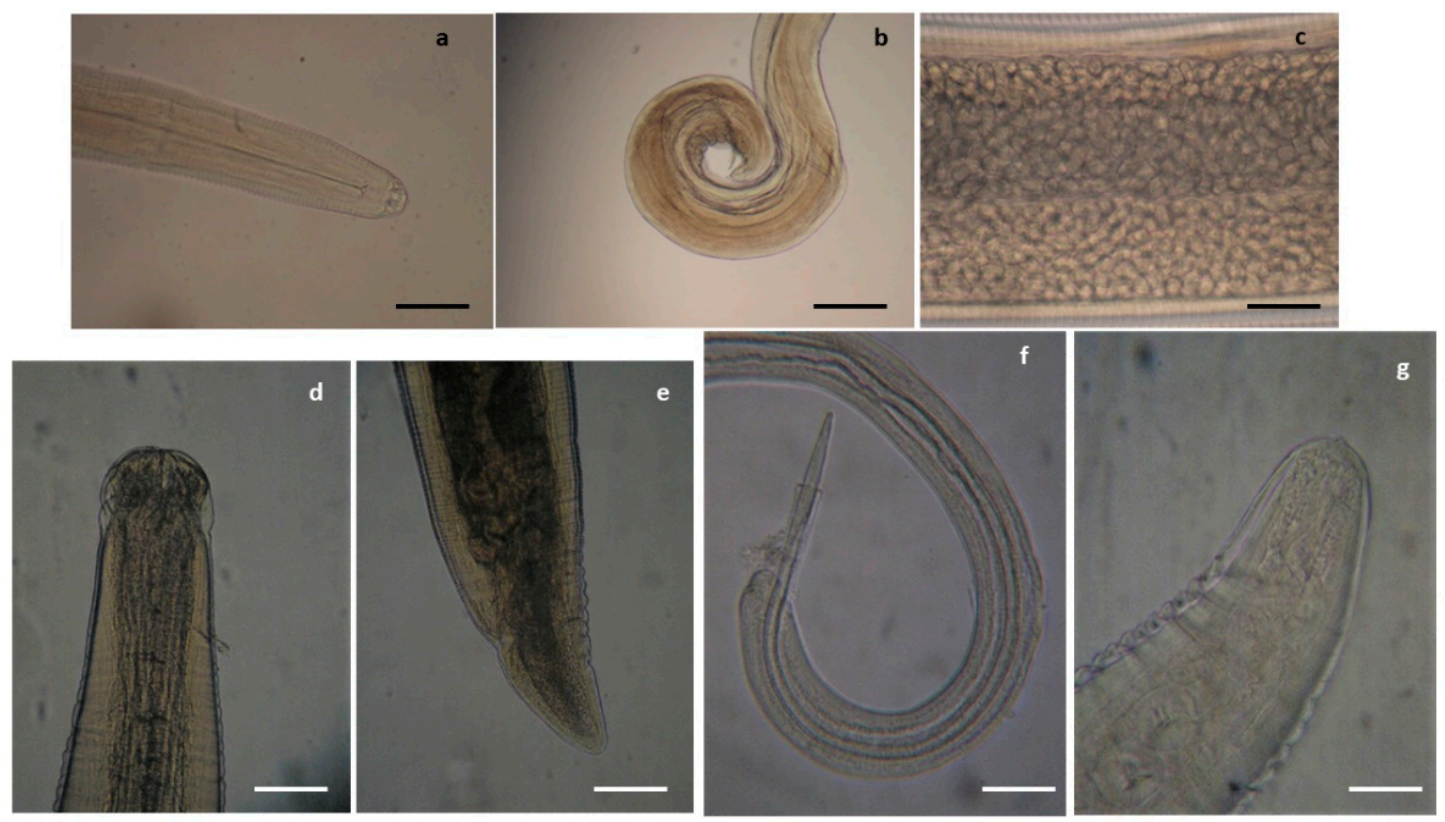

Figure 1. Nematodes identified in the common buzzard. (a) Anterior end of Procyrnea mansioni adult female, (b) caudal end of P. mansioni adult male, and (c) detail of a section of the body of a P. mansioni female showing a high number of eggs, scale bar $4 \mathrm{~mm}(\mathbf{a}, \mathbf{b}), 8 \mathrm{~mm}$ (c). Anterior (d) and caudal (e) end of Porrocoecum angusticolle adult female, scale bar $150 \mu \mathrm{m}$. (f) Caudal end of Baruscapillaria falconis adult male, scale bar $100 \mu \mathrm{m}$. Detail of the caudal end of Physaloptera alata (g), scale bar $600 \mu \mathrm{m}$. 


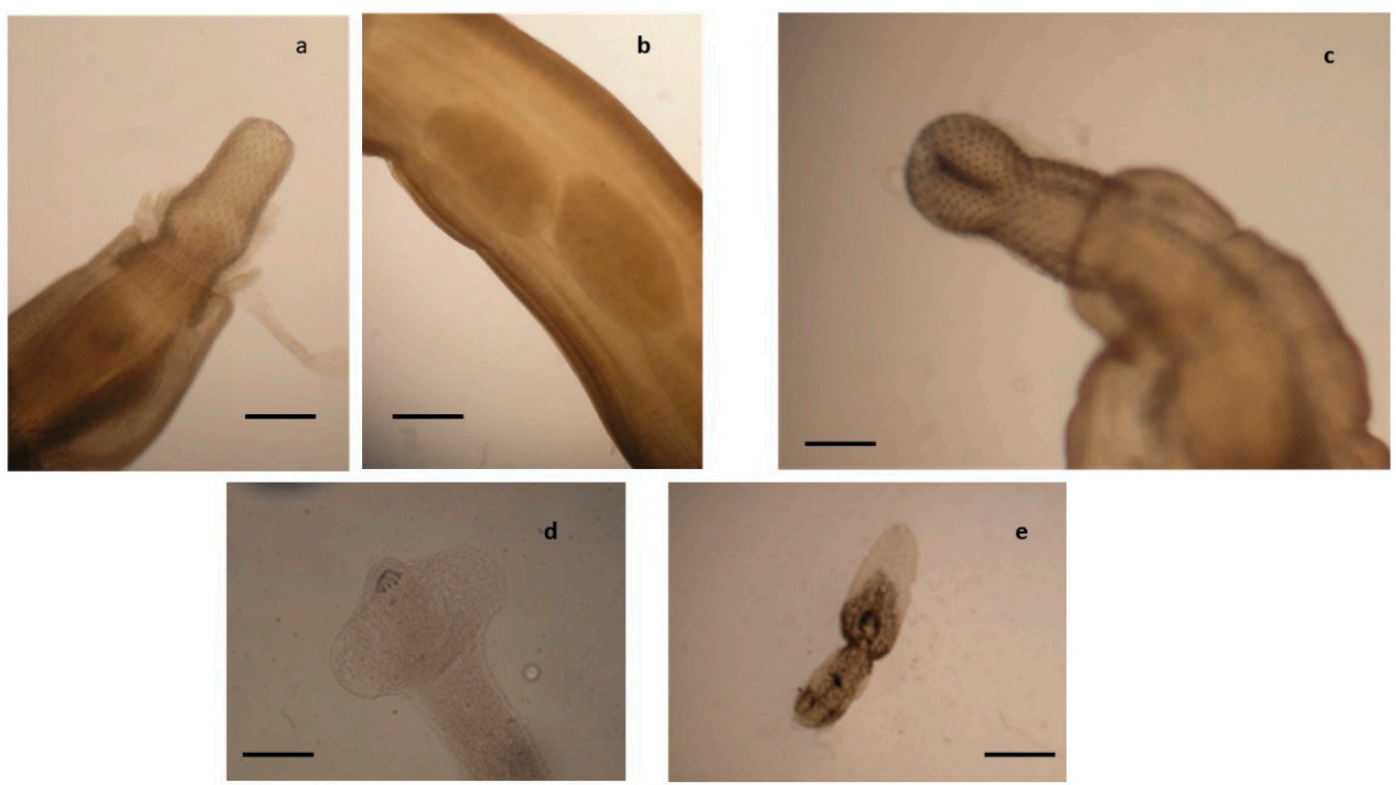

Figure 2. Acanthocephalans, cestodes, and trematodes identified in the European common buzzard (B. buteo). Anterior end (a) of Centrorhynchus globocaudatus showing the proboscis and detail of the body showing the two testicles (b), scale bar $0.6 \mathrm{~mm}$. Anterior end (c) of Centrorhynchus aluconis, scale bar $0.6 \mathrm{~mm}$. Anterior end of Cladotaenia globifera (d), scale bar $95 \mu \mathrm{m}$. (e) Neodiplostomum attenuatum $€$, scale bar $0.5 \mathrm{~mm}$.

Regarding bacteriological analysis, Salmonella typhimurium and Salmonella enterica subspecies diarizonae were detected in the liver and intestine of the common buzzard 2 and 3, respectively (Table 4). To the best of our knowledge, this study is the first report of S. typhimurium and S. enterica subspecies diarizonae in the common buzzard (B. buteo).

Gross lesions were found mainly in the digestive tract of the common buzzards 2, 3, and 4 (Table 1).

At the histopathological examination, areas of mucosal erosion, as well as hyperemia, foci of micro- and macro-granulomatosis, and chronic-active inflammation were evidenced in the gizzard and in the proventriculus of all these buzzards and especially in the isthmus in two of them (Table 3, Figure 3a,b). These lesions were found constantly observed in $P$. mansioni-infected birds, and the number and severity of these lesions were also found related to P. mansioni intensity, which was higher in two buzzards (Table 2). In previous studies [30,45], dark red nodular lesions, erosions, and ulcers of the gastric mucosa associated with Procyrnea sp. infection have been reported in diurnal raptors, including buzzards, while data on associated histological lesions are lacking.

Inflammation of the intestinal mucosa and infiltration by heterophils and macrophages and micro and macro-granulomatous lesions were also found constantly present in the large intestine of Centrorhynchus spp.-infected buzzards. These findings confirm previous observations in buzzards, and some authors consider these lesions a direct consequence of the mechanical damage caused by the proboscis these parasites use to anchor themselves to the intestinal wall [30,37].

As previously reported $[30,37,46]$, esophageal inflammation, characterized by chronic and diffuse inflammation with transmural infiltrate consisting of lymphocytes and plasma cells, was highlighted in the esophagus of the two E. dispar-infected common buzzards.

In the small intestine of a buzzard found heavily infected by B. falconis, foci of acute inflammation characterized by microscopic agglomerates composed by heterophils and eosinophils and focal mucosal erosion were highlighted (Figure 3C). Previous data on B. falconis-associated lesions are lacking. However, similar lesions have been observed in raptors infected by other intestinal capillariid species [47,48]. 

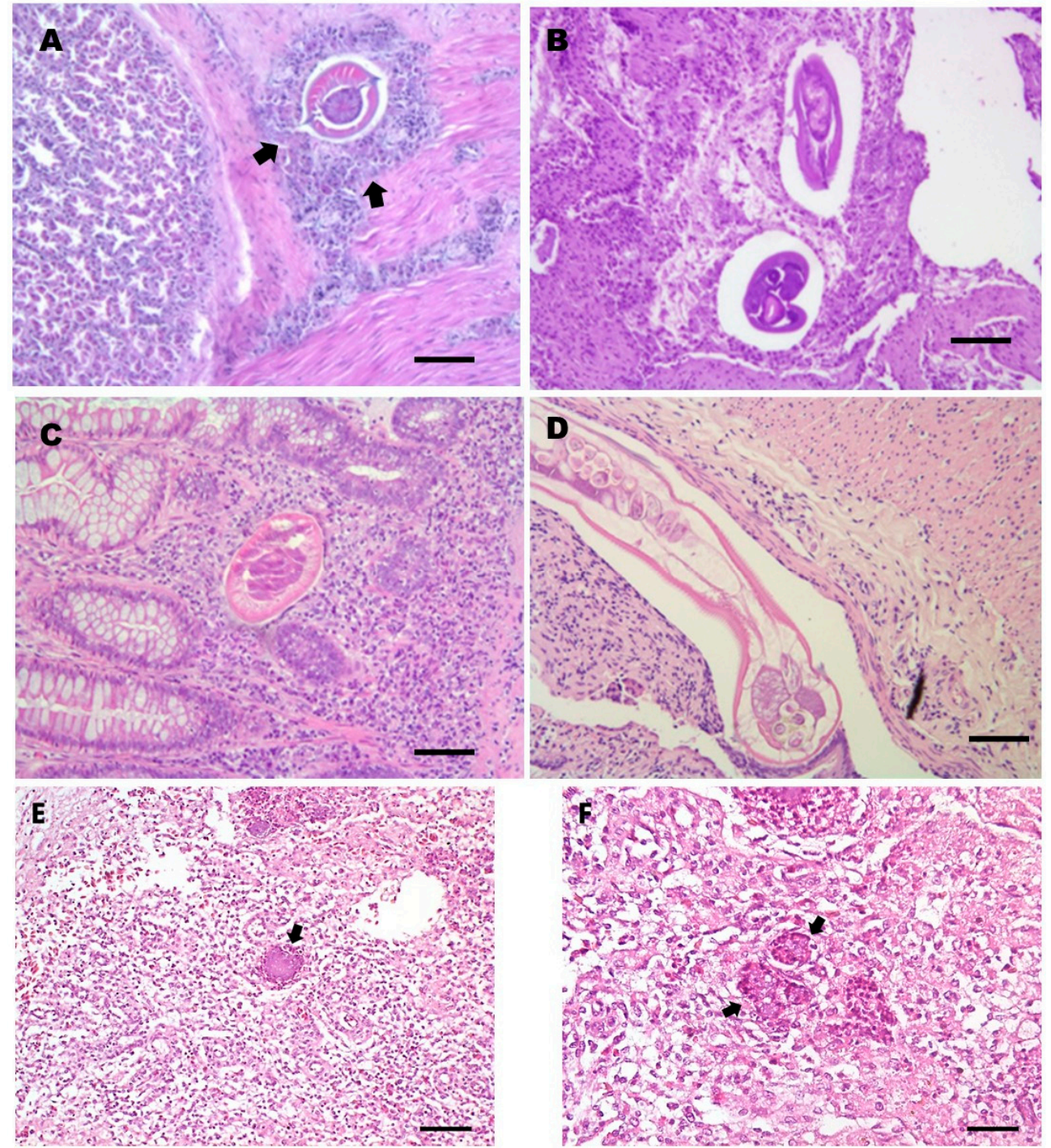

Figure 3. (A) Common buzzard (B. buteo), histology of the gizzard infected by P. mansioni, at the level of the isthmic area. Granuloma with the presence of a parasite; the granuloma wall consists of a mixed population of mono- and polymorph nuclear cells (heterophilic granulocytes, numerous lymphocytes, plasma cells, and macrophages-arrows). The lesion is recently formed and not well encapsulated by peri-nodular fibroblasts proliferation. (B) Common buzzard (B. buteo) histology of the proventriculus infected by P. mansioni: two parasites inside the mucosa can be observed, surrounded by a pyogranulomatous inflammatory infiltrate. Note the necrotic areas around the two parasites and the ulceration of the proventricular mucosa above the area of mucosal inflammation. (C) Common buzzard (B. buteo) histology of the small intestine with severe parasite colonization (mainly by $B$. falconis). The histological section shows a parasite localized in a deep portion of the mucosa in the small intestinal crypt area, surrounded by an acute inflammatory reaction, characterized by a large number of heterophils and eosinophils granulocytes, in the absence of mesenchymal reaction and/or fibrosis. (D) Honey buzzard (Pernis apivorus); histology of the jejunum parasitized by Raillietina apivori, characterized by chronic-active inflammation, infiltrating a segmental tract of the organ wall, with the presence of a parasite in the lumen. (E,F) Common buzzard (B. buteo), histology of the liver in a Salmonella typhimurium-infected bird: note the classic micro-granulomas, also called "typhoid-like" nodules, which show a center of unstructured necrosis surrounded by some inflammatory cells represented by heterophilic granulocytes and some mononuclear cells (arrows) without a capsule. H\&E; scale bar $=500 \mu \mathrm{m}(\mathrm{A}, \mathrm{B}$, and E); $250 \mu \mathrm{m}(\mathrm{C}, \mathrm{D}$, and F). 
In a common buzzard, diffuse duodenal inflammation with the presence of transmural infiltrates of lymphocytes and plasma cells was found associated with a heavy infection caused by the trematode $N$. attenuatum, confirming previous findings [30,37], while mucosal erosion and severe hyperemia were evidenced in the small intestine of a buzzard found infected by a high number of C. globifera cestodes (Table 3 ).

Moderate lesions consisting of atypical and micro-granulomatous lesions sub-miliaric in size characterized by foci of caseous necrosis surrounded by some epithelioid cells or 2-3 macrophages, lymphocytes, and heterophilic granulocytes, in the absence of an encapsulating reactive fibrous wall ("typhoid-like"nodules), were only observed at histopathological examination (Figure 3E,F) in the two Salmonella-infected buzzards (Table 3). These findings agree with those generally found in Salmonella-infected birds [49]. Salmonella spp. infections are infrequently reported in raptors $[1,46]$. However, Salmonella spp. have been detected in the feces of a variety of asymptomatic raptors, especially those living in rescue centers for wild animals [26,50-57]. Raptors can also acquire the infection by preying on infected animals $[17,28]$.

Among the two positive honey buzzards, E. dispar, Physaloptera apivori, and Raillietina apivori were identified, respectively, in the esophagus, gizzard, and intestine (Figure 3D) of honey buzzard 1 concurring with intestinal S. typhimurium infection, while honey buzzard 2 scored positive for E. dispar in the esophagus, Procyrnea leptoptera in the stomach, and B. falconis in the small intestine, along with E. coli infection in the liver (and brain) (Tables 2 and 4, Figure 4). However, macroscopic lesions of the digestive system associated with severe weight loss and dehydration were observed mainly in the honey buzzard 2 . This was also evidenced at the histopathological examination, as the presence of helminths in the esophagus and gizzard of the honey buzzard 1 was found not associated with specific lesions (Table 3), while chronic-active inflammation was found associated with $R$. apivori (Figure 3D). Conversely, granulomatous lesions were observed in the esophagus and proventriculus of the honey buzzard 2, associated with E. dispar and P. leptoptera infection, respectively. Interestingly, lesions found associated with $P$. leptoptera infection in this honey buzzard are very similar to those found in some of P. mansioni-infected European common buzzards examined here.

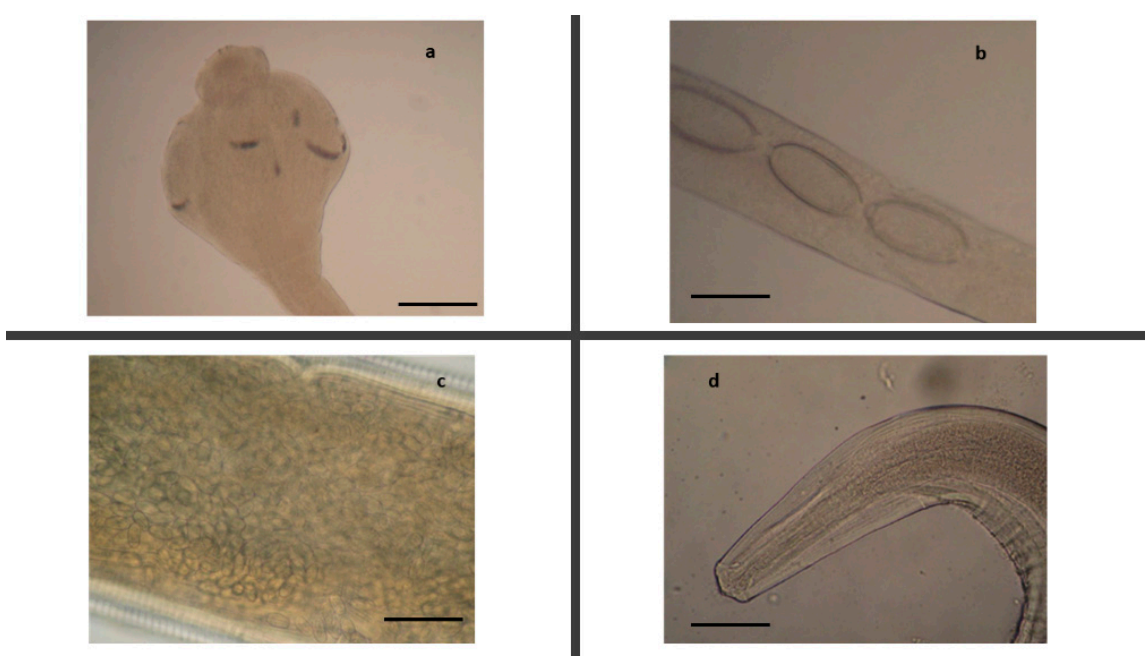

Figure 4. Parasites identified in the honey buzzard. (a) Scolex of Raillietina apivori, scale bar $200 \mu \mathrm{m}$. (b) Detail of the body of a Baruscapillaria falconis adult female with eggs, scale bar $50 \mu \mathrm{m}$. (c) Detail of the body of a Procyrnea leptoptera adult female with eggs, scale bar $2 \mathrm{~mm}$. (d) Anterior end of Physaloptera apivori, scale bar $0.4 \mathrm{~mm}$.

Furthermore, the presence of atypical sub-miliaric micro-granulomatous lesions was observed at the histopathological examination in the S. typhimurium-infected honey buzzard 1 , while chronic and diffuse inflammation with transmural infiltrates made of lymphocytes and plasma cells were highlighted throughout the intestinal tract of honey buzzard 2. 
These latter lesions, along with hepatomegaly and nephromegaly observed at necropsy, could be associated mainly with $E$. coli infection. In fact, E. coli is a bacterial pathogen often isolated from the intestinal content of diurnal birds of prey, both as a primary pathogen or a pathogen secondary to other infections $[2,18]$, and may cause acute septicemic forms or sub-acute-chronic infections characterized by voluminous granulomas, aero-sacculitis, pneumonia, pericarditis, osteomyelitis, and nephritis $[17,46]$. Clinically, diarrhea, anorexia, and respiratory distress can be also observed $[2,18,58]$.

Among positive sparrowhawks, sparrowhawk 1 showed catarrhal enteritis at necropsy, but no pathogens were detected at the bacteriological examination (Tables 1 and 4). However, at the parasitological analysis, P. leptoptera, Synhimantus (Dispharynx) falconis, and $P$. alata were identified in the proventriculus and the proximal tract of the small intestine (Table 2, Figure 5). At the histopathological examination, these parasites were found associated with foci of chronic-active inflammation, characterized by the presence of heterophiles, lymphocytes, and macrophages infiltrating the proventriculus and a segmental tract of the duodenal wall; parasites were also evidenced in the lumen of these organs (Table 3, Figure 6). As observed in the common buzzards, B. falconis found in the small intestine of this animal was instead associated with foci of acute inflammation of jejunum and ileum and with the presence of micro-agglomerates of heterophils and eosinophils, areas of mucosal erosion, and hyperemia (Table 3, Figure 7).
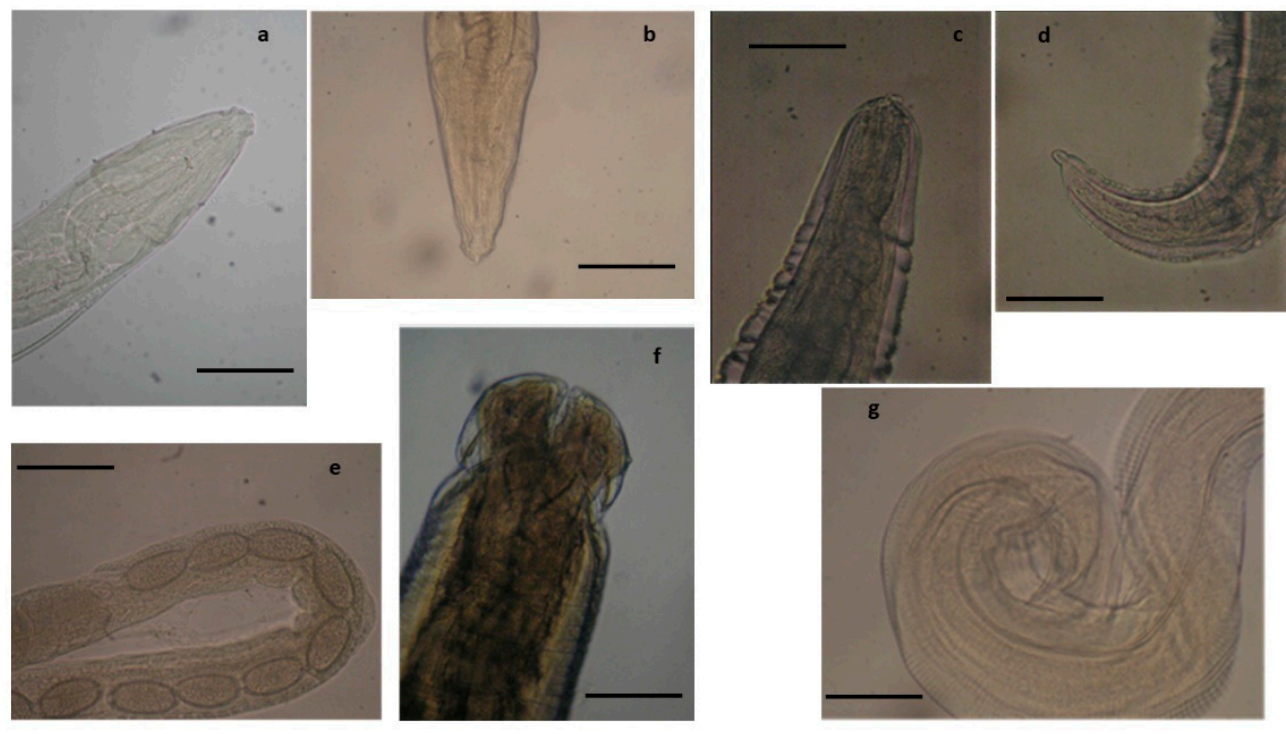

Figure 5. Nematodes identified in the sparrowhawk. Anterior (a) and posterior (b) end of Synhimantus (Dispharynx) falconis, scale bar $300 \mu \mathrm{m}$. Anterior (c) and posterior (d) end of Physaloptera alata, scale bar $500 \mu \mathrm{m}$. (e) Detail of a capillariid adult female with eggs, scale bar $70 \mu \mathrm{m}$. (f) anterior end of Porrocoecum angusticolle, scale bar $0.5 \mathrm{~mm}$. (g) posterior end of a Procyrnea leptoptera adult male, scale bar $350 \mu \mathrm{m}$.

Parasitological analysis of sparrowhawk 2 (Table 2) revealed P. leptoptera infection in the gizzard and the proventriculus associated with moderate histopathological lesions characterized by micro- and macro-granulomatous foci and ulcers on the mucosa overlying the micro-granulomatous areas (Table 3). Granulomas were characterized by a necrotic center with the presence of dystrophic calcification, with the cell wall consisting of numerous heterophilic granulocytes and macrophages and sometimes of giant cells and mixed lymphocytes and/or plasma cells. These findings agree with previous observations in sparrowhawks infected by $P$. leptoptera and with findings from this study in $P$. leptoptera and P. mansioni-infected honey and common buzzards, respectively [30,33]. 


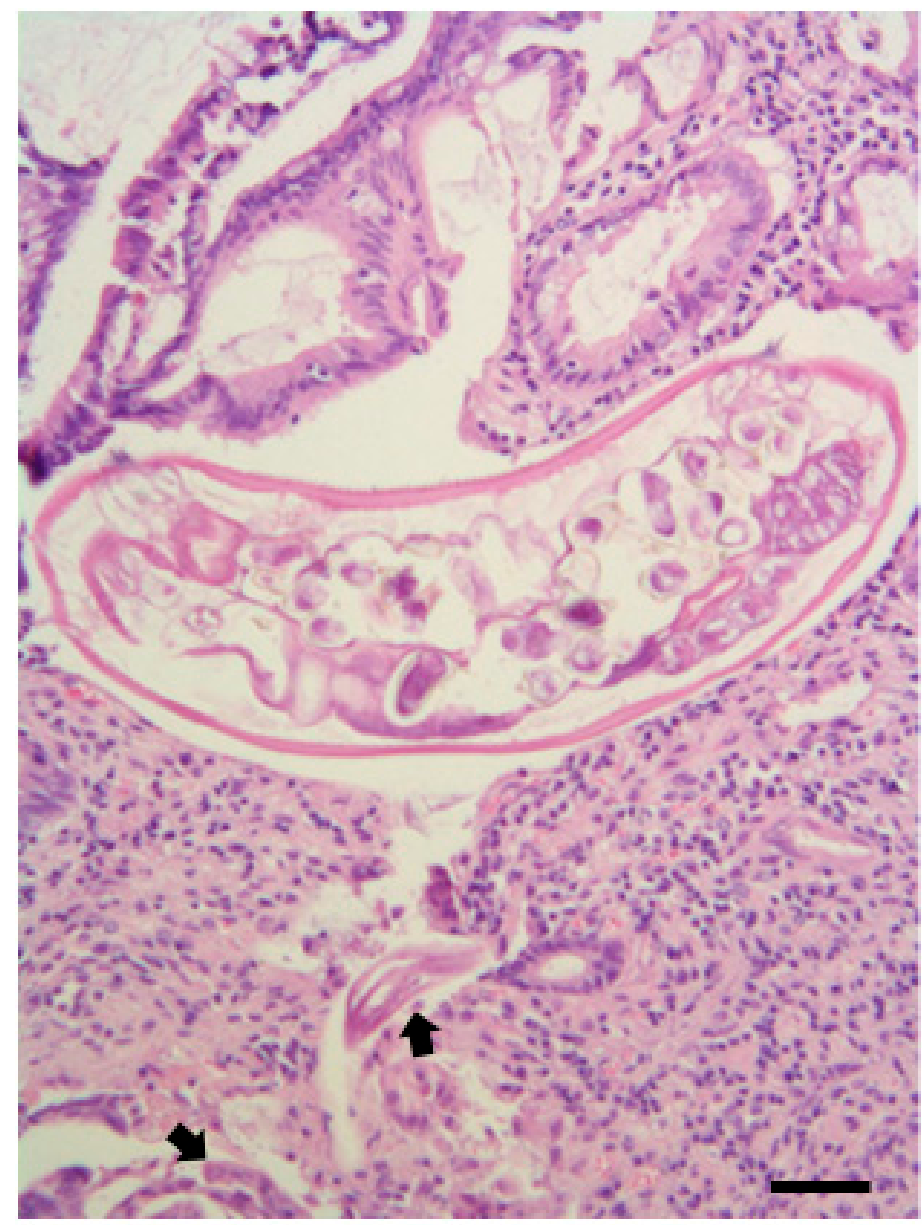

Figure 6. Eurasian sparrowhawk (A. nisus), the presence of parasites (probably Procyrnea spp.) in the duodenum. Chronic-active inflammation, characterized by the presence of heterophils, lymphocytes, and macrophages infiltrating a segmental tract of the organ wall, is observed. Note the presence of some parasites in the endoluminal area (arrows) not encysted or surrounded by a granulomatous reaction. H\&E, scale bar $=150 \mu \mathrm{m}$.

Moreover, B. falconis and Spirocerca cysts (Table 2), each containing an encysted larva, were identified in the intestine of this animal. At the histopathological examination, capillariids were evidenced in the lumen and within the mucosa of the intestine associated with diffuse chronic interstitial inflammation with the presence of transmural infiltrate of lymphocytes and plasma cells (Table 3, Figure 7).

Microscopic examination of the intestinal content of this animal also revealed the presence of a high number of protozoan sporocysts, with a mean measurement of $12.35 \times 8.72 \mu \mathrm{m}$ (range 10.9-13.08 $\times 8.72 \mu \mathrm{m}$ ) (Table 2), morphologically identifiable with Sarcocystis columbae [59]. In the whole intestinal tract, lesions and chronic diffuse inflammation were highlighted at the histological examination, with the presence of transmural infiltrates of lymphocytes and plasma cells associated with a high number of endocellular protozoa in the epithelium and the lamina propria of the small intestine (Table 3), concurrent with evident bacterial overgrowth in the crypts and glands of the intestinal mucosa.

At necropsy (Table 1), this animal also showed necrotic enteritis, and Clostridium perfringens intestinal infection was identified at bacteriological analysis (Table 4). 


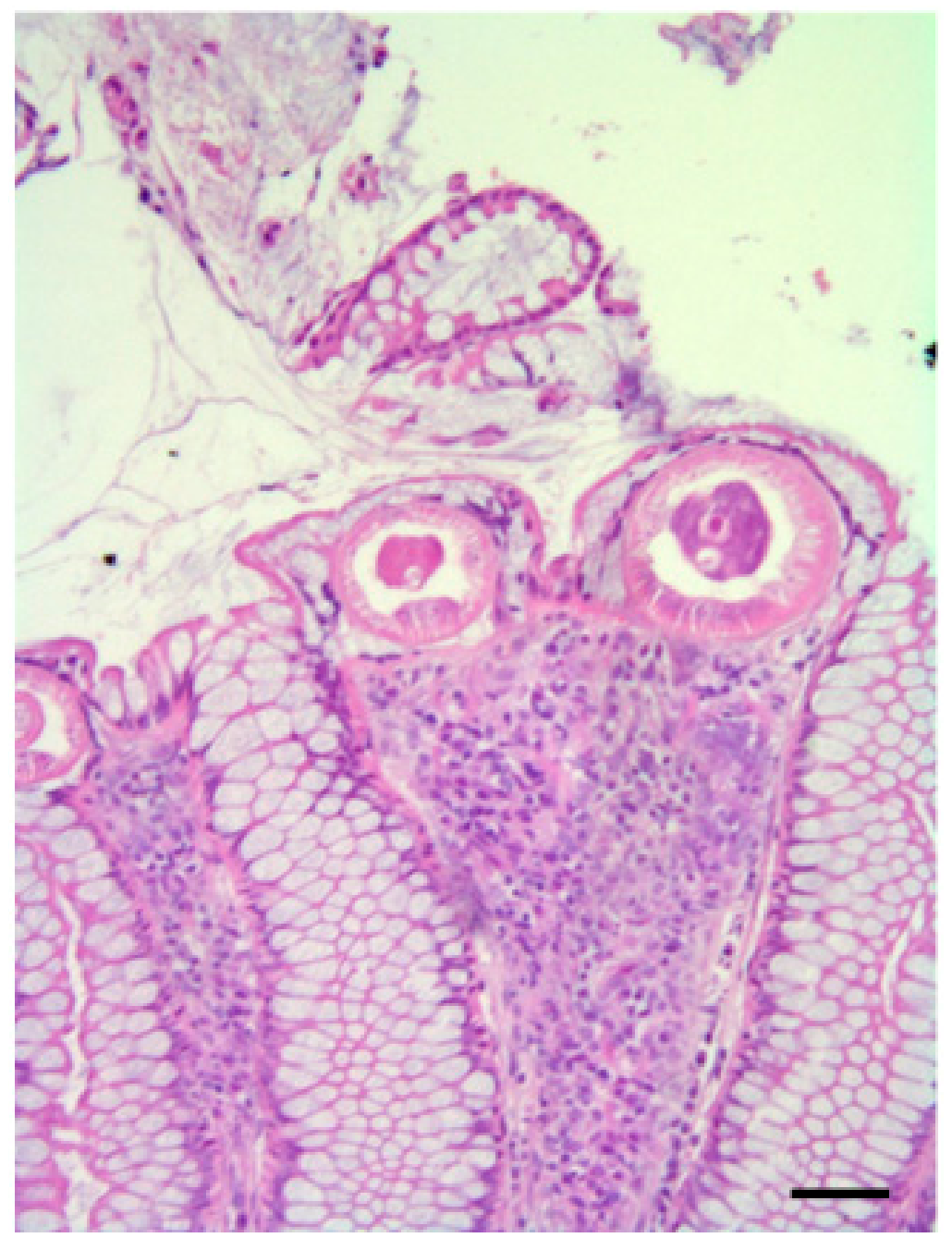

Figure 7. Presence of sub-epithelial parasites in the intestine of a B. falconis-infected Eurasian sparrow hawk (A. nisus). Diffuse chronic interstitial inflammation with the presence of transmural infiltrate of lymphocytes and plasma cells in the presence of parasites. Note the presence of diffuse mucinous metaplasia of the colonic mucosa, with a total transformation due to an overgrowth of goblet cells. H\&E; scale bar $=150 \mu \mathrm{m}$.

C. perfringens is often a component of the normal intestinal microbiome of various birds, and it is particularly frequent in Falcon raptors [18,60]. However, in the presence of concurrent factors, such as diet changes, stressful conditions, and some intercurrent infections, it can cause necrotic enteritis with diarrhea, often bloody, progressive dehydration that may also lead diseased birds to death, and secondary hepatitis and splenitis $[61,62]$. In poultry, C. perfringens is the most important causative agent of necrotic enteritis $[63,64]$, and this condition is especially observed when bacterial overgrowth concurs with a severely damaged intestinal epithelium, often due to heavy coccidian infections [64]. Therefore, the concurrent severe $S$. columbae infection and necrotic enteritis may suggest a possible role of this protozoan infection as a predisposing factor for the onset of clostridial necrotic enteritis in this bird.

Finally, sparrowhawk 3 showed hemorrhagic gastroenteritis at necropsy (Table 1). The bacteriological analysis was negative, while $B$. falconis and P. angusticolle were evidenced in the intestinal tract at the parasitological examination (Table 2, Figure 5). The histopathological examination confirmed the presence of these nematodes in the endoluminal area or attached to the mucosa, and associated lesions were similar to those observed in the B. falconis-infected sparrowhawk 2 (Table 3). 
At necropsy (Table 1), kestrel 1 showed serous and fibrin collection in the thoracoabdominal cavity and catarrhal-hemorrhagic enteritis, while the liver was dark reddish-brown in color. Three parasite species (Table 2), namely Diplotriaena falconis, Neodiplostomum spathoides, and Spirocerca spp., were identified in the intestine of this animal.

At bacteriological analysis (Table 4), Yersinia enterocolitica and P. multocida were identified in the intestine and in the brain. Y. enterocolitica has been reported in wild-living birds [65,66], including raptors [67]. Infected birds may die very rapidly after infection, or the disease may take weeks to manifest [68]. Intestinal mucinosis associate with Y. enterocolitica infection has been also reported [69]. On the other hand, P. multocida is the etiological agent of avian cholera and one of the bacterial species more frequently causing disease in birds $[46,70]$. Severe hyperacute and acute infections may occur, while hemorrhagic diarrhea, along with other signs, can be observed in sub-acute infections [46,70]. Chronic forms include serositis, necrotic foci, and small granulomatous lesions affecting all organs.

Several intestinal macro-granulomatous foci and intestinal mucinosis were observed at the histopathological examination in this bird. Interestingly, a weak inflammatory infiltrate, associated with the areas of colonic mucinosis, was typically associated to the sub-epithelial localization of some Spirocerca spp. larvae (Figure 8).

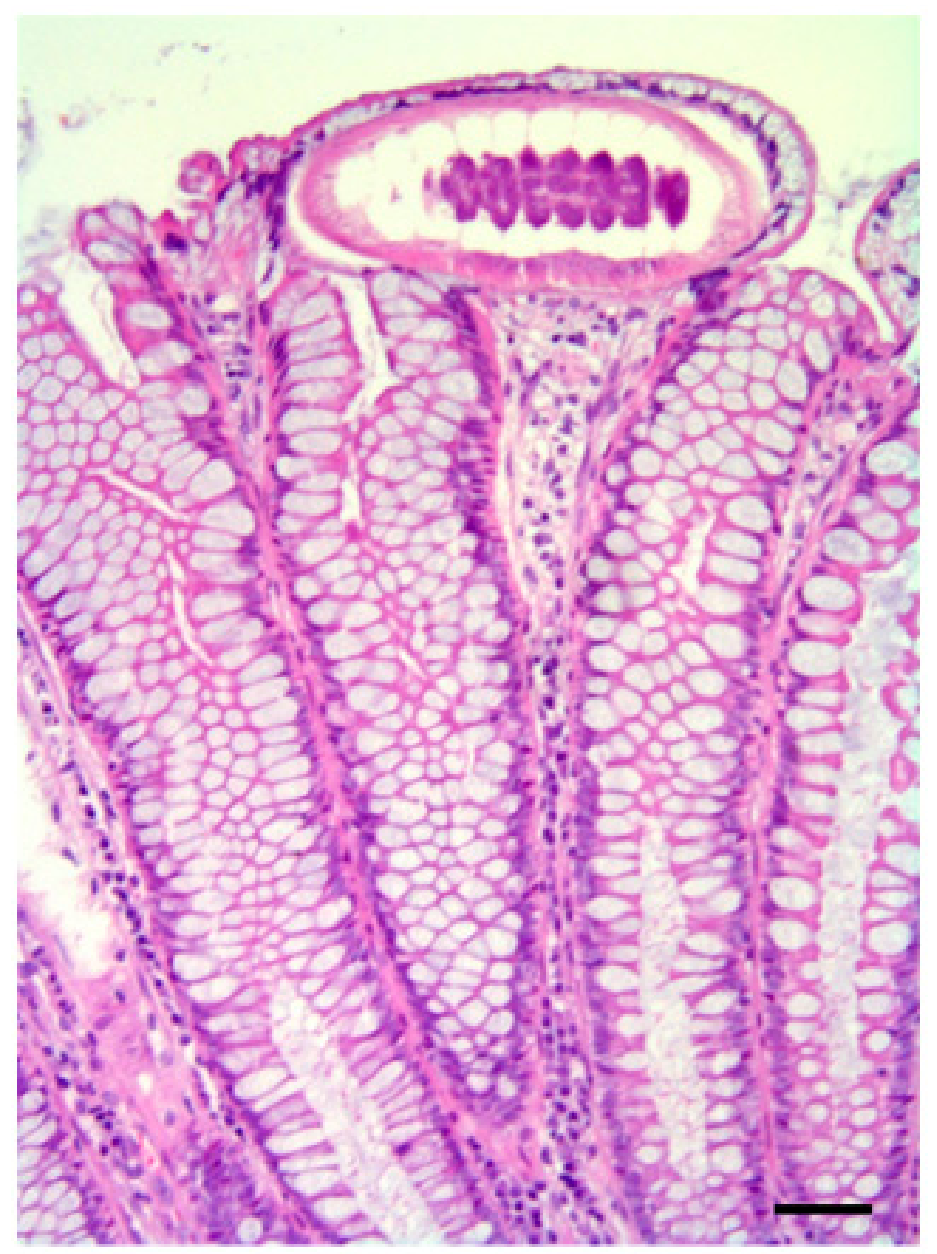

Figure 8. Large intestinal mucinosis and sub-epithelial endowed parasites in a Spirocerca spp. infected common kestrel (F. tinnunculus). Note the low chronic inflammatory infiltrate, constituted by scattered interstitial lymphocytes, without granulomatous reactions. H\&E; scale bar $=150 \mu \mathrm{m}$.

However, serositis observed in the thoracoabdominal cavity, catarrhal-hemorrhagic enteritis, and intestinal macro-granulomatous lesions, as well as liver pathological changes observed in this bird, could be due mainly to $P$. multocida, while $Y$. enterocolitica infection 
should be considered co-responsible for enteritis and sepsis and co-responsible or the main cause for intestinal mucinosis observed in this bird.

The common kestrel 2 did not show any significant lesions at necropsy, and no bacterial pathogens were identified (Tables 1 and 4). On the other hand, over 50 Synhimantus laticeps adults and a C. falconis acanthocephalan were found in the proventriculus and the intestine, respectively (Table 2, Figure 9). The histopathological examination revealed erosions of the stomach mucosa and the presence of parasites, some of which calcified, in the muscle fibers of the stomach wall that can be associated with the heavy S. laticeps infection observed in this bird, as previously reported [30,33].
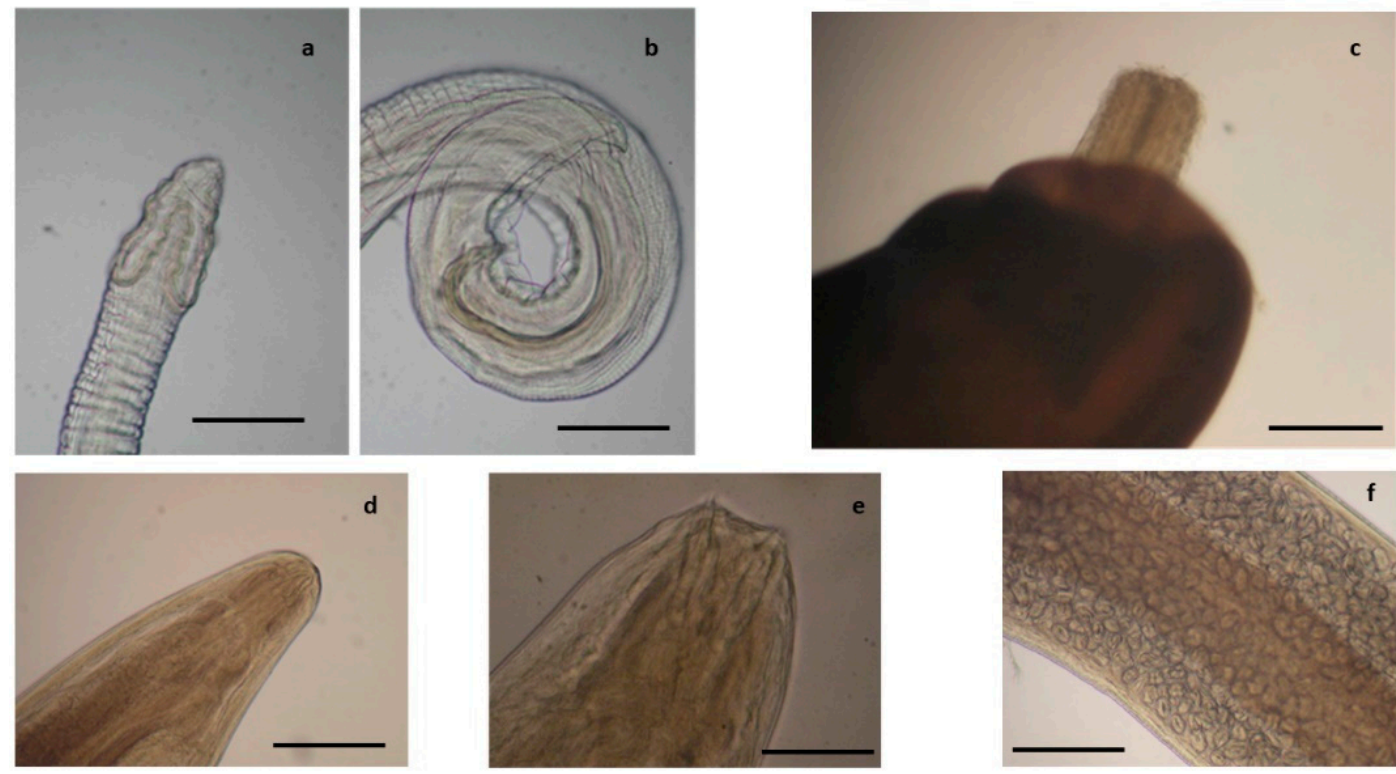

Figure 9. Some of the helminth species identified in the common kestrel (F.tinnunculus). Anterior (a) and posterior (b) end of Synhimantus laticeps adult male, scale bar $300 \mu \mathrm{m}$. (c) Anterior section of the body of Centrorhynchus falconis (d), scale bar $0.5 \mathrm{~mm}$ Anterior end of Diplotriaena falconis, scale bar $250 \mu \mathrm{m}$. Details of the body of D. falconis: (e) anterior end and (f) section of the body of a female specimen filled with eggs, scale bar $250 \mu \mathrm{m}$.

Finally, among diurnal raptors, the single osprey examined was found positive for Procyrnea leptoptera nematoda in the gizzard and proventriculus and for the acanthocephalan species Andracantha mergi in the intestine, but no bacteria were found.

Regarding nocturnal raptors, the two scops owls scored negative at the parasitological and bacteriological examinations.

The barn owl 1 (Table 1) showed enteritis associated with Sarcocystis dispersa infection, but no bacteria were identified, while parasitological and histopathological examinations of the barn owl 2 revealed Spirocerca spp. cysts in the gastric and intestinal wall along with enteritis and macro-granulomatous lesions (Tables 1-3; Figure 10).

Among positive little owls, the parasitological examination (Table 2, Figure 11) revealed Capillaria tenuissima infection in the small intestine of almost all of these birds, while little owl 2 was also found infected by P. leptoptera in the gizzard and proventriculus, and little owl 12 was infected by N. attenuatum in the intestine (Table 2). Bacteriological analysis revealed E. coli infection in the liver of little owl 6 and P. multocida infection in the liver, brain, and other organs of little owl 13, showing intestinal gross lesions, hepatomegaly, and obstruction of the cloaca, suggesting septicemia (Table 4). At the histopathological examination (Table 3), diffuse chronic inflammation with transmural infiltrates of lymphocytes and plasma cells was instead highlighted in the gizzard, proventriculus, and the entire intestinal tract of this bird, which was probably caused by P. multocida $[46,70]$. Severe intestinal dysmicrobism and damage to the intestinal epithelium, especially in the duodenum, were also evidenced. 


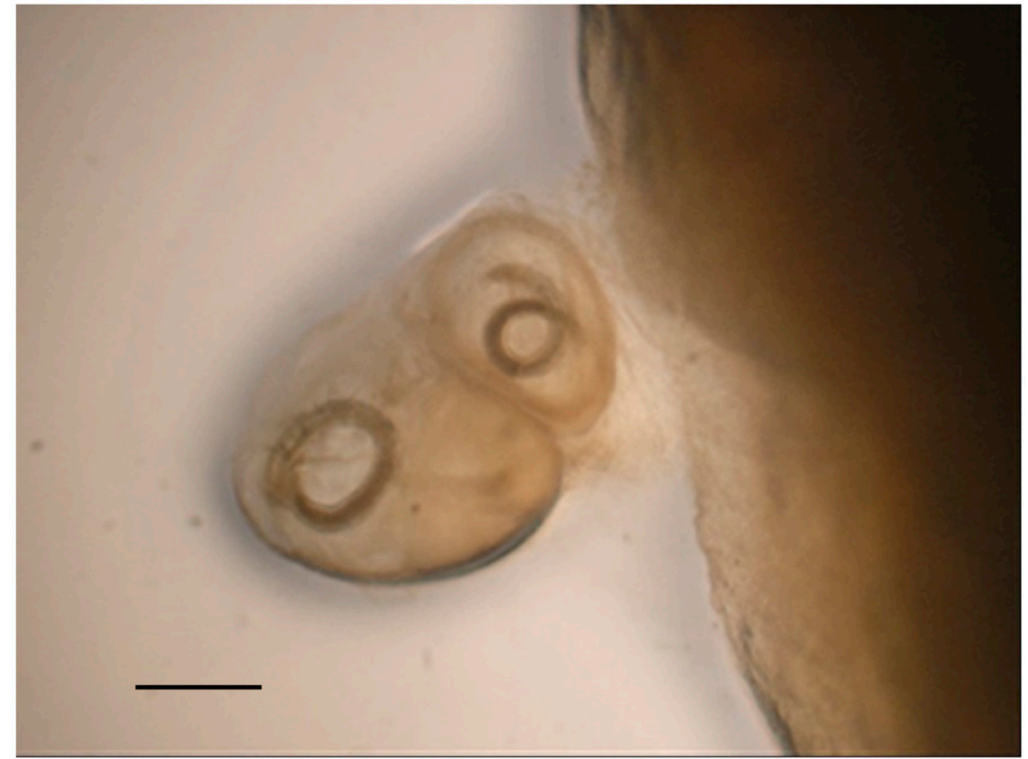

Figure 10. Spirocerca spp. cysts in the intestinal wall of the barn owl 2, scale bar $750 \mu \mathrm{m}$.
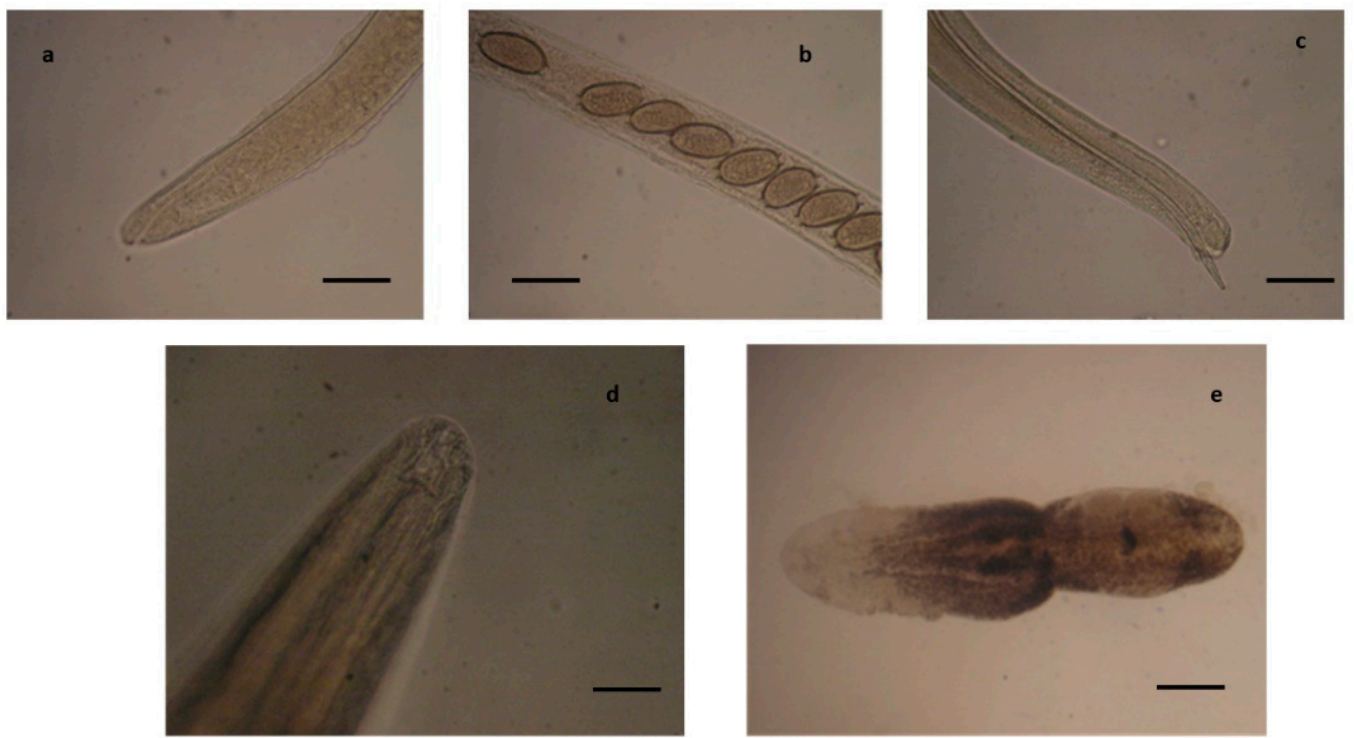

Figure 11. Helminths identified in the little owls. Anterior end (a) and a detail of the body with eggs (b) of an adult female and caudal end (c) of an adult male of Capillaria tenuissima, scale bar $80 \mu \mathrm{m}$. (d) Anterior end of Procyrnea leptoptera, scale bar $350 \mu \mathrm{m}$. (e) Neodiplostomum attenuatum, scale bar $350 \mu \mathrm{m}$.

C. tenuissima infection was instead found constantly associated with diffuse chronic inflammation of mild severity with transmural infiltrates of lymphocytes and plasma cells or with foci of acute inflammation, micro-aggregates of heterophils, and eosinophils. Areas of mucosal erosion and hyperemia were instead found associated with $N$. attenuatum infections. Moreover, mild atypical micro-granulomatous lesions were also found in the jejunal and ileal tract of little owl 6, probably due to E. coli infection [18]. In little owl 12, a heavy colonization of coccidian parasites, identifiable with Eumonospora mochogalegoi or Eumonospora henryae previously reported in the little owl [71], was also evidenced at histopathology (Figure 12). 


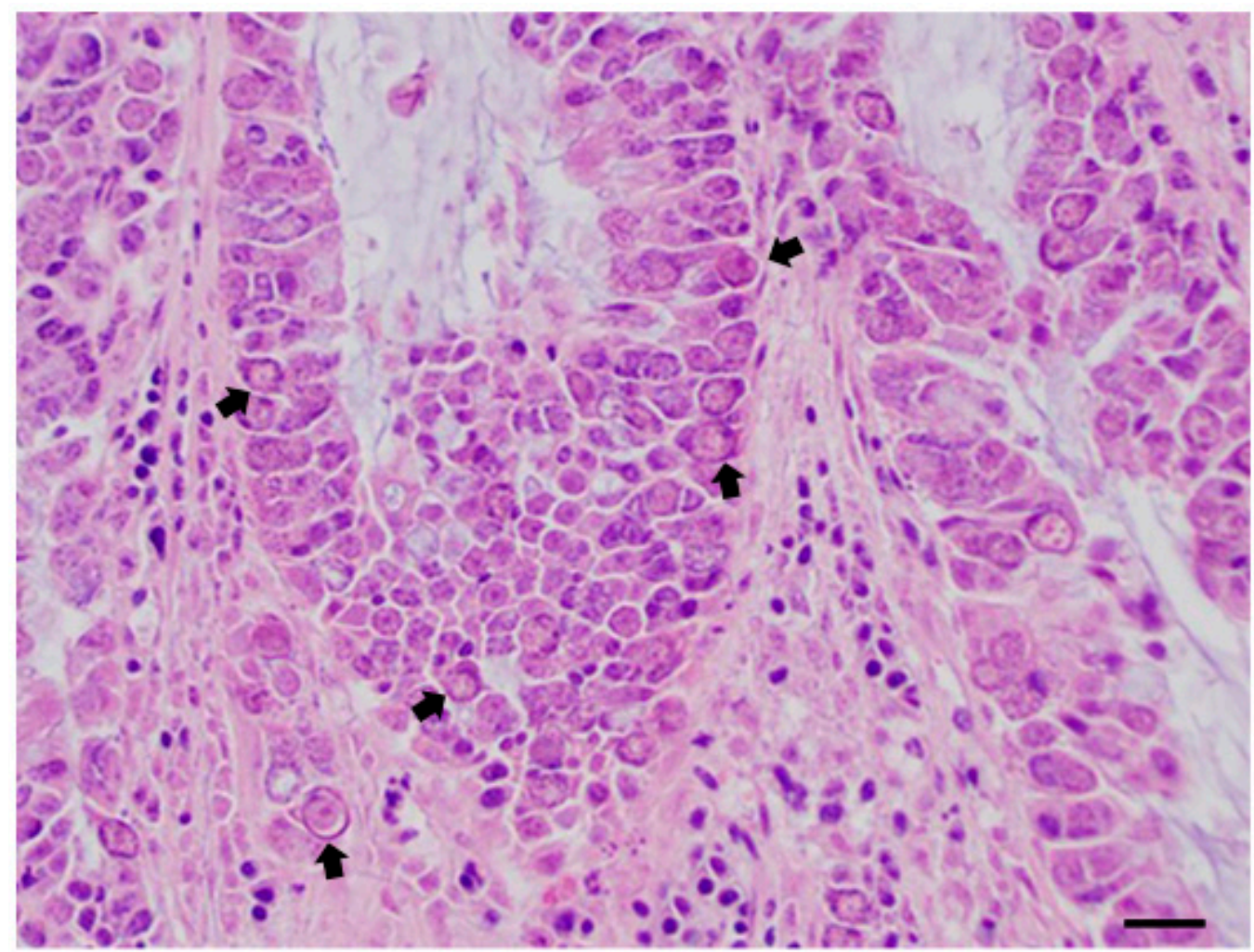

Figure 12. Jejunal mucosa of little owl (A. noctua); chronic inflammatory infiltrate in an interstitial diffuse form, associated with the large presence of apicomplexan protozoa in the epithelium (various stages of the life cycle-arrows) or inside macrophages interspersed in the intestinal wall. H\&E; scale bar $=100 \mu \mathrm{m}$.

\section{Materials and Methods}

\subsection{Animals}

Twenty-nine deceased diurnal and nocturnal raptors were examined from 2003 to 2005 for endoparasites and bacteria (Table 1). The examined diurnal raptors (Accipitriformes and Falconiformes) included four common buzzards (B. buteo), two European honey buzzards (P. apivorus), three sparrowhawks (A. nisus), two common kestrels (F. tinnunculus), and a western osprey (P. haliaetus) (Table 1). Among nocturnal raptors (Strigiformes), two barn owls (T. alba), thirteen little owls (A. noctua), and two scops owls (O. scops) were examined (Table 1). All the raptors examined in this study had died from a few hours to ten days after their arrival in wildlife rescue centers located in the district of Lucca $\left(43^{\circ} 50^{\prime} \mathrm{N}, 10^{\circ} 30^{\prime} \mathrm{E}\right)$ (Tuscany, central Italy), with the exception of a barn owl (T. alba) that was found dead in a wildlife rescue center located in the district of Livorno $\left(43^{\circ} 33^{\prime} \mathrm{N}, 10^{\circ} 18^{\prime} \mathrm{E}\right.$, Tuscany, central Italy) and a common kestrel (F. tinnunculus) that was found dead in the district of Pisa $\left(43^{\circ} 43^{\prime} \mathrm{N}, 10^{\circ} 23^{\prime} \mathrm{E}\right.$, Tuscany, central Italy). The examined birds had not been treated with antiparasitic drugs and were single-caged. In most cases, deceased birds were placed in clean bags, refrigerated, and transported to the laboratory soon after their death. All examined birds were necropsied, and bacteriological and parasitological analysis of the different tracts of the digestive system were performed. Organs that scored positive for the presence of endoparasites and/or bacteria underwent further histopathological examinations.

\subsection{Necropsy}

An external examination was performed to evaluate eventual abnormalities of muscle masses, subcutaneous fat, and mucous membranes. All organs and systems were examined to assess the presence of macroscopic lesions. 


\subsection{Bacteriological Analysis}

Brain, intestine, and liver samples taken from all birds were cultured on several culture media specific for the search of different selected bacteria, including Salmonella spp., Escherichia coli, Yersinia spp., Pasteurella spp., and Clostridium spp. [72].

For Salmonella spp., samples were inoculated in Buffered Peptone Water and incubated at $37^{\circ} \mathrm{C}$ for $18 \mathrm{~h}$. After incubation, the samples were inoculated into Rappaport-Vassiliadis soya broth (Oxoid, Milan, Italy) and incubated at $42{ }^{\circ} \mathrm{C}$ for $18 \mathrm{~h}$. The cultures obtained were plated onto Xylose-lysinedeoxycholate agar (Oxoid, Milan, Italy) and Brilliant Green Agar (Oxoid, Milan, Italy), incubated at $37{ }^{\circ} \mathrm{C}$, and examined after $24 \mathrm{~h}$. Suspected colonies were then sub-cultured in nutrient agar, and the confirmation of Salmonella species was performed using oxidase, API 20E (BioMérieux, Florence, Italy), and polyvalent antisera. Salmonella spp. isolates were serotyped according to the Kauffmann-White scheme in collaboration with The Reference Center for Pathogenic Enterobacteria (IZSLT, Rome, Italy).

To isolate E. coli, samples were inoculated onto Colombia blood agar base (Oxoid, Milan, Italy) and MacConkey agar (Oxoid, Milan, Italy) and incubated at $37^{\circ} \mathrm{C}$ for $18 \mathrm{~h}$. The biochemical identification was performed using a miniaturized biochemical test galleries API 20E system (BioMérieux, Florence, Italy).

For Clostridium perfringens isolation, samples were inoculated onto Colombia blood agar base (Oxoid, Milan, Italy), incubated at $37^{\circ} \mathrm{C}$ for $24-48 \mathrm{~h}$ anaerobically, and the glove box was used with the AnaeroGen (Oxoid, Milan, Italy). The identification of colonies with specific characteristics ( $\beta$-haemolytic and lecithinase positive) was performed using API rapid 32A and API 20A (BioMérieux, Florence, Italy).

The isolation of Yersinia spp. was performed by direct inoculation in cold preenrichment broth phosphate-buffered saline and incubated at $25{ }^{\circ} \mathrm{C}$ for $48 \mathrm{~h}$. After incubation, the samples were inoculated onto Colombia blood agar base (Oxoid, Milan, Italy), MacConkey agar (Oxoid, Milan, Italy) and Yersinia selective agar base cefsulodin-irgasannovobiocin (Oxoid, Milan, Italy) with incubation at $30^{\circ} \mathrm{C}$ for $24-48 \mathrm{~h}$. The confirmation of Yersinia enterocolitica was performed using oxidase, urease, and miniaturized biochemical test by using test galleries API 20E (BioMérieux, Florence, Italy).

For Pasteurella multocida, samples were inoculated onto Colombia blood agar base (Oxoid, Milan, Italy), MacConkey agar (Oxoid, Milan, Italy), and brain heart infusion agar broth and incubated at $24-48 \mathrm{~h}$ at $37^{\circ} \mathrm{C}$. The confirmation of P. multocida was obtained using oxidase and miniaturized biochemical test galleries API 20 NE (BioMérieux, Florence, Italy).

\subsection{Parasitological Analysis}

The whole digestive (liver, gall bladder, esophagus, stomach, duodenum, jejunumileum, ceca, and cloaca) system was opened. A batch of intestinal tract content samples was microscopically examined under an optical microscope, both as fresh smears and after the flotation test with saturated $\mathrm{NaCl}$ solution (specific gravity 1.2), to detect the presence of nematode eggs or protozoa cysts/oocysts/sporocysts. Then, each opened digestive tract was washed in saline and subjected to sedimentation in a refrigerator for approximately $24 \mathrm{~h}$. After this time, the sediment was observed under a stereoscope to assess the presence of adult helminths that were collected, counted, washed in saline solution, and fixed in a glycerin-ethanol solution (medium of Looss). Helminths were cleared in lactophenol on a glass slide for identification under an optical microscope and then returned to the preservative. All measurements were taken with the aid of a micrometric eyepiece.

The identification of parasite genus/species was performed based on keys or descriptions given in previous studies [40,41,48,59,73-84].

\subsection{Histopathological Analysis}

Organs from 18 raptors, including common buzzards (B. buteo, $n=4)$, Eurasian sparrowhawks (A. nisus, $n=3$ ), European honey buzzards (P. apivorus, $n=2)$, common kestrels (F. tinnunculus, $n=2)$, barn owls (T. alba, $n=1)$, and little owls (A. noctua, $n=6)$, scored positive for parasites and/or bacteria, were processed for histopathological examination. 
Fragments of at least $2.5 \mathrm{~cm}$ in length of the esophagus, proventriculus, ventriculus, duodenum, jejunum/ileum, and colon were collected. Samples were fixed in $10 \%$ neutral buffered formalin for a period of $24 \mathrm{~h}$ and routinely processed. Three-micrometer paraffin sections were placed on Superfrost Plus slides (Histoline, Milan, Italy). The slides were then dewaxed and stained with hematoxylin and eosin stain (H\&E) for microscopic examination. The morphological evaluation of each digestive tract was carried out, with the determination of the location of the parasite and, in the case of an evident histological lesion, the characterization of the inflammation (acute, chronic-active, granulomatous inflammation). Moreover, the sections found infected by parasites were stained with Shiff's Periodic Acid (PAS).

The following parameters were used for the histological evaluation: for each lesion, a score evaluation was performed considering as: grade 0 (negative $=$ lesion not observed); grade from 1 to 3 (indicated with the + sign) the progressive degree of the lesions. The lesion score was therefore $1(+)=$ minor lesion; $2(++)=$ moderate lesion; $3(+++)=$ severe lesion. To characterize the lesions, a letter from $A$ to $G$ was used, as described in the caption of Table 3.

\section{Conclusions}

Worldwide, raptors are included among animals more frequently admitted to wildlife recovery centers. Moreover, many raptor populations are highly threatened, mainly due to human activities. Therefore, the collection of data on pathogens and associated lesions in raptors living in a specific area can provide useful information for enhancing raptor conservation efforts, reducing pathogen transmission between raptors, domesticated animals, and humans, and improving the knowledge on raptor pathogens.

To the best of the authors' knowledge, this study is the first organic investigation on endoparasite infections and associated bacteria and pathological lesions of the digestive tract of European raptors. Although most of the pathogens identified in this study are commonly found in European diurnal and nocturnal raptors, this study is the first report of S. typhimurium and S. enterica subspecies diarizonae in the common buzzard (B. buteo) and the first report in Italy of the parasite species Andracantha mergi, Spirocerca spp., Sarcocystis dispersa, Sarcocystis columbae, and Eumonospora spp.

The results obtained showed that both parasites, especially when in high number, and /or pathogenic bacteria may cause severe lesions in the digestive system of diurnal and nocturnal raptors; parasites and bacteria may concur in causing these lesions; and most severe lesions are caused by the interaction of multiple pathogens, both parasites and bacteria. Moreover, in most cases, the same parasite genus/species was frequently found associated with the same type of lesions in the histopathological analysis. The potential role of these birds for the dispersal of bacteria potentially pathogenic for humans, such as Salmonella spp. and Y. enterocolitica, and domesticated animals was also highlighted. Although the characterization of some bacteria, such as E. coli, was not performed in this study, the obtained data are indicative of associated septicemic forms. Finally, the severity of pathological changes found associated with parasitic and/or bacterial pathogens in some of these raptors could have greatly impaired the function of the digestive system and, in some cases, may have represented the main cause for the death of these birds.

Author Contributions: Conceptualization, S.P.; methodology, all authors; validation, all authors; formal analysis, all authors; investigation, all authors; resources, S.P., G.T., R.G. and G.R.; data curation, S.P.; writing—original draft preparation, S.P.; writing—review and editing, S.P., G.T. and L.G.; visualization, S.P., G.T. and G.R.; supervision, S.P.; project administration, S.P.; funding acquisition, S.P., G.T. and G.R. All authors have read and agreed to the published version of the manuscript.

Funding: This research received no external funding.

Institutional Review Board Statement: Not applicable.

Informed Consent Statement: Not applicable. 


\section{Data Availability Statement: Not applicable.}

Acknowledgments: The authors thank Antonio Barsanti and the wild animal rehabilitation centers for providing the deceased birds examined in this study.

Conflicts of Interest: The authors declare no conflict of interest.

\section{References}

1. Molina-Lopez, R.A.; Casal, J.; Darwich, L. Causes of Morbidity in Wild Raptor Populations Admitted at a Wildlife Rehabilitation Centre in Spain from 1995-2007: A Long Term Retrospective Study. PLoS ONE 2011, 6, e24603. [CrossRef]

2. Gargiulo, A.; Fioretti, A.; Russo, T.P.; Varriale, L.; Rampa, L.; Paone, S.; De Luca Bossa, L.M.; Raia, P.; Dipineto, L. Occurrence of enteropathogenic bacteria in birds of prey in Italy. Lett. Appl. Microbiol. 2018, 66, 202-206. [CrossRef] [PubMed]

3. González-Rubio, S.; Ballesteros-Gómez, A.; Asimakopoulos, A.G.; Jaspers, V.L.B. A review on contaminants of emerging concern in European raptors (2002-2020). Sci. Total Environ. 2021, 760, 143337. [CrossRef]

4. Donázar, J.A.; Cortés-Avizanda, A.; Fargallo, J.A.; Margalida, A.; Moleón, M.; Morales-Reyes, Z.; Moreno-Opo, R.; Pérez-García, J.M.; Sánchez-Zapata, J.A.; Zuberogoitia, I.; et al. Roles of Raptors in a Changing World: From Flagships to Providers of Key Ecosystem Services. Ardeola 2016, 63, 181-234. [CrossRef]

5. Italian Law n. 157/1992. Legge 11 Febbraio 1992, n. 157. Norme per la Protezione della Fauna Selvatica Omeoterma e per il Prelievo Venatorio. Gazzetta Ufficiale della Repubblica Italiana Serie Generale n.46 del 25-02-1992-Suppl. Ordinario n. 41. Available online: https:/ / www.gazzettaufficiale.it/eli/id/1992/02/25/092G0211/sg (accessed on 21 June 2021).

6. International Union for Conservation of Nature (IUCN). Available online: https://www.iucn.org/ (accessed on 21 June 2021).

7. King, J.C.; Dubay, S.A.; Huspeni, T.C.; VanLanen, A.R.; Gerhold, R.W. Parasite infections in nestling red-shouldered hawks (Buteo lineatus) in northeast Wisconsin. J. Parasitol. 2010, 96, 535-540. [CrossRef]

8. Papazahariadou, M.; Diakou, A.; Papadopoulos, E.; Georgopoulou, I.; Komnenou, A.; Antoniadou-Sotiriadou, K. Parasites of the digestive tract in free-ranging birds in Greece. J. Nat. Hist. 2008, 42, 381-398. [CrossRef]

9. Oro, D.; Genovart, M.; Tavecchia, G.; Fowler, M.S.; Martınez-Abraın, A. Ecological and evolutionary implications of food subsidies from humans. Ecol. Lett. 2013, 16, 1501-1514. [CrossRef]

10. Movalli, P.; Krone, O.; Osborn, D.; Pain, D. Monitoring contaminants, emerging infectious diseases and environmental change with raptors, and links to human health. Bird Study 2018, 65 (Suppl. S1), S96-S109. [CrossRef]

11. Blanco, G.; Díaz de Tuesta, J.A. Seasonal and spatial occurrence of zoonotic Salmonella serotypes in griffon vultures at farmland environments: Implications in pathogen pollution and ecosystem services and disservices. Sci. Total Environ. 2021, 758, 143681. [CrossRef]

12. Espín, S.; García-Fernández, A.J.; Herzke, D.; Shore, R.F.; van Hattum, B.; Martínez-López, E.; Coeurdassier, M.; Eulaers, I.; Fritsch, C.; Gómez-Ramírez, P.; et al. Tracking pan-continental trends in environmental contamination using sentinel raptors-what types of samples should we use? Ecotoxicology 2016, 25, 777-801. [CrossRef] [PubMed]

13. Macaluso, A. Aiutiamo i rapaci di casa nostra. Sci. Vet. Biol. Anim. 1985, 4, 37-41.

14. Perry-Jones, J. Understanding Owls: Biology, Management, Breeding, Training; David \& Charles: Devon, UK, 1998.

15. Cerasoli, M.; Penteriani, V. Primi risultati dell'indagine sui centri di recupero rapaci in Italia. In Proceedings of the Quinto Convegno Italiano di Ornitologia, Bracciano, Italy, 4-8 October 1989; SROPU (Stazione Romana Osservazione e Protezione Uccelli), Ed.; Istituto Nazionale di Biologia della Selvaggina: Bologna, Italy, 1991; pp. 299-307.

16. Marrow, J.; Whittington, J.K.; Mitchell, M.; Hoyer, L.L.; Maddox, C. Prevalence and antibiotic-resistance characteristics of Enterococcus spp. isolated from free-living and captive raptors in Central Illinois. J. Wildl. Dis. 2009, 45, 302-313. [CrossRef] [PubMed]

17. Benskin, C.M.; Wilson, K.; Jones, K.; Hartley, I.R. Bacterial pathogens in wild birds: A review of the frequency and effects of infection. Biol. Rev. Camb. Philos Soc. 2009, 84, 349-373. [CrossRef] [PubMed]

18. Vidal, A.; Baldomà, L.; Molina-López, R.A.; Martin, M.; Darwich, L. Microbiological diagnosis and antimicrobial sensitivity profiles in diseased free-living raptors. Avian Pathol. 2017, 46, 442-450. [CrossRef] [PubMed]

19. Lacina, D.; Bird, D.M. Endoparasites of raptors-A review and an update. In Raptor Biomedicine III; Lumeij, J.T., Remple, J.D., Redig, P.T., Lierz, M., Cooper, J.E., Eds.; Zoological Education Network, Inc.: Lake Worth, FL, USA, 2000; pp. 65-78.

20. Krone, O.; Cooper, J.E. Parasitic Diseases chapter 7. In Birds of Prey Birds of Prey: Health E Disease, 3rd ed.; Cooper, J.E., Ed.; Blackwell Science Ltd.: Oxford, UK, 2002. [CrossRef]

21. Tarello, W. Leucocytozoon toddi in falcons from Kuwait: Epidemiology, clinical signs and response to melarsomine. Parasite 2006, 13, 179.

22. Tarello, W. Clinical signs and response to primaquine in falcons with Haemoproteus tinnunculi infection. Vet. Rec. 2007, 161, 204-205. [CrossRef]

23. Illescas Gomez, M.P.; Rodriguez Osorio, M.; Aranda Maza, F. Parasitation of falconiform, strigiform and passeriform (Corvidae) birds by helminths in Spain. Res. Rev. Parasitol. 1993, 53, 129-135.

24. Borgsteede, F.H.M.; Okulewicz, A.; Zoun, P.E.F.; Okulewicz, J. The helminth fauna of birds of prey (Accipitriformes, Falconiformes and Strigiformes) in the Netherlands. Acta Parasitol. 2003, 48, 200-207. 
25. Krone, O. Endoparasites. In Raptor Research and Management Techniques; Bird, D.M., Bildstein, K.L., Eds.; Hancock House Publishers: Washington, DC, USA, 2007; pp. 318-328.

26. Battisti, A.; Di Guardo, G.; Agrimi, U.; Bozzano, A.I. Embryonic and neonatal mortality from salmonellosis in captive bred raptors. J. Wildl. Dis. 1998, 34, 64-72. [CrossRef]

27. Smith, O.M.; Snyder, W.E.; Owen, J.P. Are we overestimating risk of enteric pathogen spillover from wild birds to humans? Biol. Rev. Camb. Philos Soc. 2020, 95, 652-679. [CrossRef]

28. Tizard, I. Salmonellosis in wild birds. Semin. Avian Exot. Pet. 2004, 13, 50-66. [CrossRef]

29. Thomas, N.J.; Bunikis, J.; Barbour, A.G.; Wolcott, M.J. Fatal spirochetosis due to a relapsing fever-like Borrelia sp. in a northern spotted owl. J. Wildl. Dis. 2002, 38, 187-193. [CrossRef]

30. Santoro, M.; Tripepi, M.; Kinsella, J.M.; Panebianco, A.; Mattiucci, S. Helminth infestation in birds of prey (Accipitriformes and Falconiformes) in Southern Italy. Vet. J. 2010, 186, 119-122. [CrossRef]

31. Krone, O. Endoparasites in free-ranging birds of prey in Germany. In Raptor Biomedicine III; Lumeij, J.T., Remple, J.D., Redig, P.T., Lierz, M., Cooper, J.E., Eds.; Zoological Education Network, Inc.: Lake Worth, FL, USA, 2000; pp. 101-116.

32. Childs-Sanford, S.; Lejeune, M.; Abdu, A.; Buckles, E.; Renshaw, R.; Ford, D.; Bunting, E. Oral Capillariosis Due to Eucoleus dispar in Migrating Sharp-shinned Hawks (Accipiter striatus) in New York, USA, 2016-2018. J. Wildl. Dis. 2019, 55, 928-934. [CrossRef]

33. Santoro, M.; D'Alessio, N.; Di Prisco, F.; Kinsella, J.M.; Barca, L.; Degli Uberti, B.; Restucci, B.; Martano, M.; Troisi, S.; Galiero, G.; et al. The occurrence and pathogenicity of Serratospiculum tendo (Nematoda: Diplotriaenoidea) in birds of prey from southern Italy. J. Helminthol. 2016, 90, 294-297. [CrossRef]

34. Sanmartin, M.L.; Alvarez, F.; Barreiro, G.; Leiro, J. Helminth fauna of Falconiform and Strigiform birds of prey in Galicia, Northwest Spain. Parasitol. Res. 2004, 92, 255-263. [CrossRef]

35. Komorová, P.; Špakulová, M.; Hurníková, Z.; Uhrín, M. Acanthocephalans of the genus Centrorhynchus (Palaeacanthocephala: Centrorhynchidae) of birds of prey (Falconiformes) and owls (Strigiformes) in Slovakia. Parasitol. Res. 2015, 114, 2273-2278. [CrossRef]

36. Dipineto, L.; Borelli, L.; Pepe, P.; Fioretti, A.; Caputo, V.; Cringoli, G.; Rinaldi, L. Synanthropic birds and parasites. Avian Dis. 2013, 57, 756-758. [CrossRef]

37. Santoro, M.; Kinsella, J.M.; Galiero, G.; degli Uberti, B.; Aznar, F.J. Helminth community structure in birds of prey (Accipitriformes and Falconiformes) in southern Italy. J. Parasitol. 2012, 98, 22-29. [CrossRef]

38. Santoro, M.; Mattiucci, S.; Nascetti, G.; Kinsella, J.M.; Di Prisco, F.; Troisi, S.; D’Alessio, N.; Veneziano, V.; Aznar, F.J. Helminth communities of owls (strigiformes) indicate strong biological and ecological differences from birds of prey (Accipitriformes and Falconiformes) in southern Italy. PLoS ONE 2012, 7, e53375. [CrossRef]

39. Kinsella, M.J.; Cole, R.A.; Forrester, D.J.; Roderick, C.L. Helminth Parasites of the Osprey, Pandion haliaetus, in North America. J. Helminthol. Soc. Wash. 1996, 63, 262-265.

40. Ebmer, D.; Wiedermann, S.; Sattmann, H. Morphological identifications of gastrointestinal nematodes and acanthocephalans of raptors and owls from Austria. Ann. Naturhist. Mus. Wien B 2020, 122, 169-174.

41. Guo, N.; Sitko, J.; Chen, H.X.; Li, L. Morphological and genetic characterization of Porrocaecum angusticolle (Molin, 1860) (Nematoda: Ascaridomorpha) from the common buzzard Buteo buteo (Linnaeus) (Accipitriformes: Accipitridae) in Czech Republic. Parasitol Int. 2021, 83, 102365. [CrossRef]

42. Honisch, M.; Krone, O. Phylogenetic relationships of Spiruromorpha from birds of prey based on 18S rDNA. J. Helminthol. 2008, 82, 129-133. [CrossRef] [PubMed]

43. Komorová, P.; Sitko, J.; Špakulová, M.; Hurníková, Z. Intestinal and liver flukes of birds of prey (Accipitriformes, Falconiformes, Strigiformes) from Slovakia: Uniform or diverse compound? Parasitol. Res. 2016, 115, 2837-2844. [CrossRef]

44. Tezel, M.; Girisgin, A.M.; Birlik, S.; Yildirimhan, H.S.; Senlik, B. Helminths of the digestive tract in Buteo buteo (Falconiformes: Falconidae) in Bursa Province of Northwest Turkey. Turk. J. Zool. 2015, 39, 323-327. [CrossRef]

45. Arrona-Rivera, A.E.; Sánchez-Godoy, F.D.; Hernández-Velasco, X. Proventricular parasitosis by Procyrnea sp. (Spiruroidea: Habronematidae) in a roadside hawk (Rupornis magnirostris) from the state of Veracruz, Mexico: A case report. Acta Zool. Mex 2016, 32, 225-229.

46. Morishita, T.Y.; Aye, P.P.; Brooks, D.L. A Survey of Diseases of Raptorial Birds. J. Avian Med. Surg. 1997, 11, 77-92.

47. Clausen, B.; Gudmundsson, F. Causes of mortality among free-ranging gyrfalcons in Iceland. J. Wildl. Dis. 1981, 17, 105-109. [CrossRef] [PubMed]

48. Deem, S.L. Infectious and Parasitic Diseases of Raptors. Compend. Cont. Educ. Pract. Vet. 1999, 21, $329-338$.

49. Henderson, S.C.; Bounous, D.I.; Lee, M.D. Early events in the pathogenesis of avian salmonellosis. Infect. Immun. 1999, 67, 3580-3586. [CrossRef]

50. Wernery, U.; Wernery, R.; Zachariah, R.; Kinne, J. Salmonellosis in relation to chlamydiosis and pox and Salmonella infections in captive falcons in the United Arab Emirates. Zentralbl. Veterinarmed. B 1998, 45, 577-583. [CrossRef]

51. Reche, M.P.; Jimenez, P.A.; Alvarez, F.; Garcia de los Rios, J.E.; Rojas, A.M.; De Pedro, P. Incidence of salmonellosis in captive and free-living raptorial birds in central Spain. J. Med. B Infect. Dis. Vet. Public Health 2003, 50, 42-44. [CrossRef]

52. Tardone, R.; Rivera, D.; Dueñas, F.; Sallaberry-Pincheira, N.; Hamilton-West, C.; Adell, A.D.; Moreno-Switt, A.I. Salmonella in Raptors and Aquatic Wild Birds in Chile. J. Wildl. Dis. 2020, 56, 707-712. [CrossRef] 
53. Bangert, R.L.; Ward, A.C.S.; Stauber, E.H.; Cho, B.R.; Widders, P.R. A Survey of the Aerobic Bacteria in the Feces of Captive Raptors. Avian Dis. 1988, 32, 53-62. [CrossRef]

54. Kirkpatrick, C.E.; Colvin, B.A. Salmonella spp. in nestling common barn owls (Tyto alba) from southwestern New Jersey. J. Wildl. Dis. 1986, 22, 340-343. [CrossRef]

55. Kirkpatrick, C.E.; Trexler-Myren, V.P. A survey of free-living falconiform birds for Salmonella. J. Am. Vet. Med. Assoc. 1986, 189, 997-998. [PubMed]

56. Winsor, D.K.; Bloebaum, A.P.; Mathewson, J.J. Gram-negative, aerobic, enteric pathogens among intestinal microflora of wild turkey vultures (Cathartes aura) in west central Texas. Appl. Environ. Microbiol. 1981, 42, 1123-1124. [CrossRef]

57. Millán, J.; Aduriz, G.; Moreno, B.; Juste, R.A.; Barral, M. Salmonella isolates from wild birds and mammals in the Basque Country (Spain). Rev. Sci. Tech. 2004, 23, 905-911. [CrossRef]

58. Gabrisch, K.; Zwart, P. Medicina e Chirurgia dei Nuovi Animali da Compagnia. Uccelli, 1st ed.; UTET: Torino, Italy, $2001 ;$ p. 428.

59. Olias, P.; Olias, L.; Lierz, M.; Mehlhorn, H.; Gruber, A.D. Sarcocystis calchasi is distinct to Sarcocystis columbae sp. nov. from the wood pigeon (Columba palumbus) and Sarcocystis sp. from the sparrowhawk (Accipiter nisus). Vet. Parasitol. 2010, 171, 7-14. [CrossRef] [PubMed]

60. Naldo, J.L.; Samour, J.H. Causes of Morbidity and Mortality in Falcons in Saudi Arabia. J. Avian Med. Surg. 2004, 18, 229-241. Available online: https://www.jstor.org/stable/27823389. [CrossRef]

61. Muller, M.G.; Mannil, T.M.; George, A.R. Study on the most common bacterial infections in falcons in the United Arab Emirates. In Proceedings of the 27th Annual AAV Conference, San Antonio, TX, USA, 6-10 August 2006; pp. 311-318.

62. Timbermont, L.; Haesebrouck, F.; Ducatelle, R.; Van Immerseel, F. Necrotic enteritis in broilers: An updated review on the pathogenesis. Avian Pathol. 2011, 40, 341-347. [CrossRef] [PubMed]

63. McReynolds, J.L.; Byrd, J.A.; Anderson, R.C.; Moore, R.W.; Edrington, T.S.; Genovese, K.J.; Poole, T.L.; Kubena, L.F.; Nisbet, D.J. Evaluation of immunosuppressants and dietary mechanisms in an experimental disease model for necrotic enteritis. Poult. Sci. 2004, 83, 1948-1952. [CrossRef] [PubMed]

64. Williams, R.B.; Marshall, R.N.; La Ragione, R.M.; Catchpole, J. A new method for the experimental production of necrotic enteritis and its use for studies on the relationships between necrotic enteritis, coccidiosis and anticoccidial vaccination of chickens. Parasitol. Res. 2003, 90, 19-26. [CrossRef]

65. Hubálek, Z.; Rudolf, I. Vertebrates as Hosts and Reservoirs of Zoonotic Microbial Agents. Microb. Zoonoses Sapronoses 2010, 10, 83-128. [CrossRef]

66. Niskanen, T.; Waldenström, J.; Fredriksson-Ahomaa, M.; Olsen, B.; Korkeala, H. virF-positive Yersinia pseudotuberculosis and Yersinia enterocolitica found in migratory birds in Sweden. Appl. Environ. Microbiol. 2003, 69, 4670-4675. [CrossRef] [PubMed]

67. Shayegani, M.; Stone, W.B.; DeForge, I.; Root, T.; Parsons, L.M.; Maupin, P. Yersinia enterocolitica and related species isolated from wildlife in New York State. Appl. Environ. Microbiol. 1986, 52, 420-424. [CrossRef] [PubMed]

68. Novotny, M.; Feckova, M.; Janiga, M.; Lukan, M.; Novotna, M.; Kovalcikova, Z. High Incidence of Yersinia enterocolitica (Enterobacteriaceae) in Alpine Accentors Prunella collaris of the Tatra Mountains. Acta Ornithol. 2007, 42, 137-143. [CrossRef]

69. Mantle, M.; Thakore, E.; Hardin, J.; Gall, D.G. Effect of Yersinia enterocolitica on intestinal mucin secretion. Am. J. Physiol. Gastrointest. Liver Physiol. 1989, 256, G319-G327. [CrossRef] [PubMed]

70. Morishita, T.Y.; Lowenstine, L.J.; Hirsh, D.C.; Brooks, D.L. Pasteurella multocida in raptors: Prevalence and characterization. Avian Dis. 1996, 40, 908-918. [CrossRef]

71. Chou, S.; Izawa, N.; Ike, K.; Tokiwa, T. Detection of Eumonospora henryae (Apicomplexa: Sarcocystidae) from Falco columbarius (Falconiformes: Aves): Comparison of host-parasite phylogram and comments on the family Sarcocystidae Poche, 1913. Int. J. Parasitol. Parasites Wildl. 2021, 14, 75-83. [CrossRef] [PubMed]

72. Carter, G.R.; Cole, J.R. Diagnostic Procedures in Veterinary Bacteriology and Mycology; Holt, J.G., Krieg, N.R., Sneath, P.H.A., Staley, J.T., Williams, S.T., Eds.; Academic Press Inc.: San Diego, CA, USA, 1990; pp. 529-561.

73. Anderson, R.C.; Chabaud, A.G.; Willmont, S. Keys to the Nematode Parasites of Vertebrates; Anderson, R.C., Chabaud, A.G., Willmott, S., Eds.; Commonwealth Agricoltural Bureaux, Farnham Royal Bucks: London, UK, 1984.

74. Skrjabin, K.I. Key to the Trematodes of Animals and Man; University of Illinois Press: Urbana, IL, USA, $1964 ;$ p. 351.

75. Skrjabin, K.I. Key to Parasitic Nematode Vol. I, Spirurata and Filariata; Skrjabin, K.I., Ed.; Israel Program for Scientific Translations; Academy of Sciences of the URSS: Moscow, Russia, 1969; p. 479.

76. Skrjabin, K.I.; Shikhobalova, N.P.; Orlov, I.V. Trichocephalidae and Capillaridae of Animals and Man and Diseases Caused by Them; Academy of sciences of the URSS: Moscow, Russia, 1970.

77. Yamaguti, S. Systema Helminthum, Volumes I-V; Interscience Publisher: New York, NY, USA, 1963.

78. Lierz, A.; Göbel, T.; Schuster, R. Review and investigation on parasites in birds of prey and owls found injured or debilitated. Berl. Münch. Tierärzl. Wschr. 2002, 115, 43-52.

79. Imai, S.; Ikeda, S.; Ishii, T.; Uematsu, K. Diplotriaena falconis (Connal, 1912) (Filariidae, Nematoda) from a red-legged falconet, Microhierax caerulescens. Jpn. J. Vet. Sci. 1989, 51, 209-212. [CrossRef] [PubMed]

80. Ali, S.M. Habronema spp. from Indian birds. J. Helminthol. 1961, 35, 1-48. [CrossRef]

81. Ali, S.M. On some new species of Physaloptera from Indian birds. J. Helminthol. 1961, 35, 49-60. [CrossRef]

82. Sitko, J. Trematodes of birds of prey (Falconiformes) in Czech Republic. Helminthologia 1998, 35, 131-146. 
83. Sitko, J. Trematodes of owls (Aves: Strigiformes) in the Czech Republic. Acta Soc. Zool. Bohem. 2001, 65, 45-56.

84. Bray, R.A.; Gibson, D.I.; Jones, A. Keys to the Trematoda; CABI Publishing: Wallingford, UK; The Natural History Museum: London, UK, 2008; Volume 3, p. 824. 